\title{
The Effectiveness of Foreign Aid in Rural
}

Development of Afghanistan

\section{A Case Study in Panjshir Province of \\ Afghanistan}

Park Chung Hee School of Policy and Saemaul of Yeungnam

University

Department of Saemaul and International Development

Saemaul Undong and Community Development Major

Sardarwali Amarkhil

Advisor: PARK Seung Woo, PhD

2017 February 


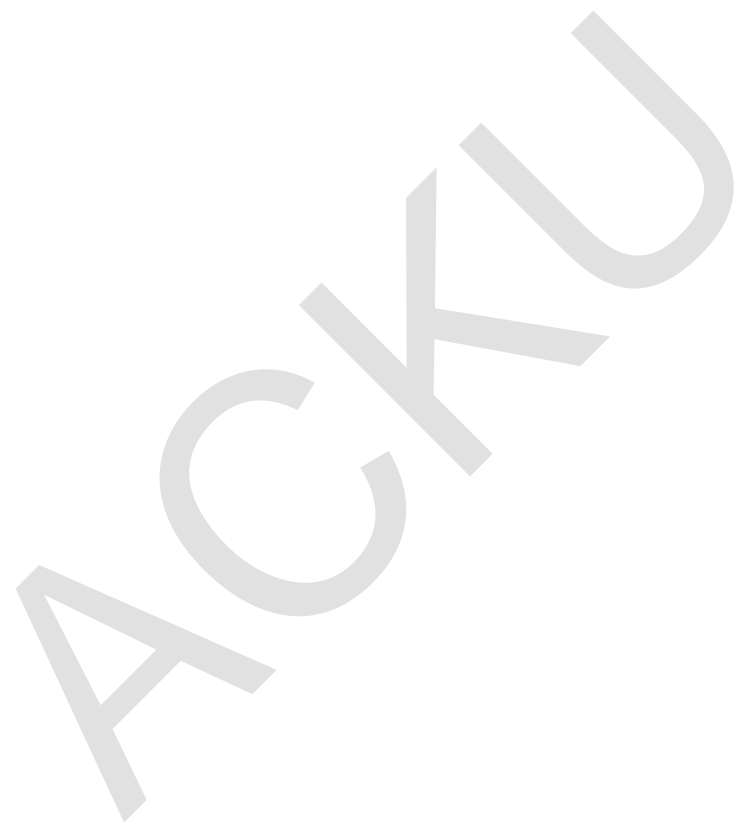




\section{The Effectiveness of Foreign Aid in Rural Development of Afghanistan} A Case Study in Panjshir Province of Afghanistan

Advisor: PARK Seung Woo, PhD

Presented as Master of Public Administration Thesis February 2017

Park Chung Hee School of Policy and Saemaul of Yeungnam University

Department of Saemaul and International Development, Saemaul Undong and Community Development Major 


\section{Sardarwali Amarkhil's Master of Public}

\section{Administration Thesis is approved}

Committee Chairman: HUH Chang Deog

(Signature)

Committee Member: LEE Misook

(Signature)

Committee Member: PARK Seung Woo

(Signature)

February 2017

Park Chung Hee School of Policy and Saemaul of Yeungnam University 


\section{Acknowledgement}

It is almost impossible to make a full list of people who have contributed to the current research project. However, I would like to thank as many as I can. Firstly, I thank Almighty Allah for giving me all the grace, power, confidences and patients for successful completion of this degree. Also, I am praying to Almighty Allah for providing more power, confidence, and patience for successful completion of my future educational objectives.

I feel proud in expressing my deepest sense of gratitude to Dr. Park Seung Woo, Dean of the Park Chung Hee School of Policy and Saemaul of Yeungnam University who is the advisor of this project. His scholastic, consistent advice, encouraging behavior, valuable suggestion, personal interest and effective supervision enabled me to complete the present Project. This research work was hard to accomplish without his cooperation.

I would like to thank Professor HUH Chang Deog, Professor LEE Misook and our entire team of lecturers who's extremely well and encouraging behaviors lead us to accomplish the program. I will not forget to thank the entire management team of the PSPS, and I will greatly appreciate my sponsor institute, KOICA, and the Korean government for providing me with this opportunity to know the rapid development of Korean community.

Last, of all, no acknowledgment could ever express my intense gratitude to my loving dad, mom, brothers, sisters, my wife and my lovely daughter, Mina Mahsa Jan, because my success is really the result of their constant prayers and motivations. I can never compensate their boundless love and kindness; especially I would like to devote my success and Masters accomplishment to my caring, loving and supporting parents.

My unique and deepest thanks go to my Afghanistan community friends and Ministry of Rural Rehabilitation and Development (MRRD) colleagues who have helped me to complete this great opportunity. And at the end, I am thankful to all my fellows who created a very friendly and pleasant environment, whose good memories will remain forever with me.

Thank you

February 2017

Sardarwali Amarkhil 


\section{Table of Contents}

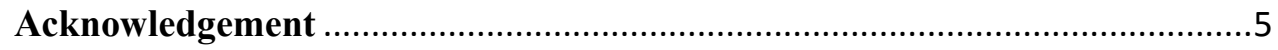

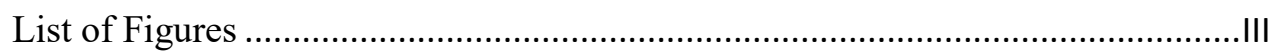

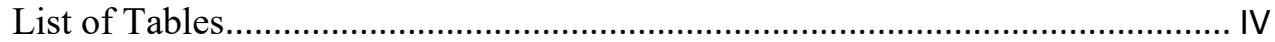

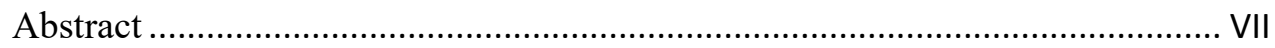

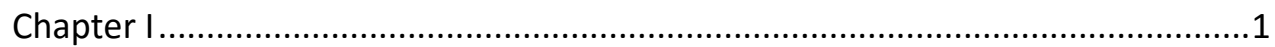

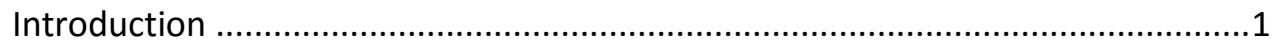

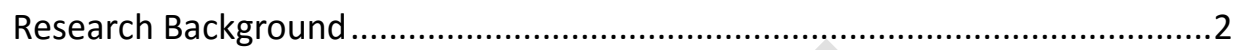

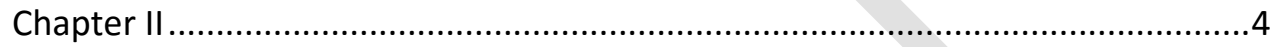

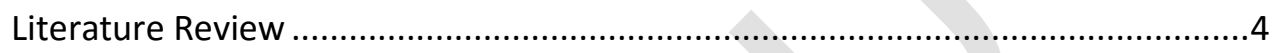

Foreign Aid History of Afghanistan ..............................................................

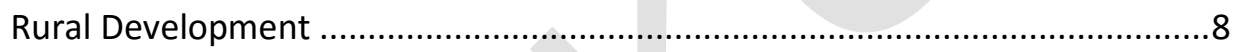

Challenges of Rural Development in Afghanistan ..............................................9

Weakened and Incapacitated Infrastructure ................................................12

Rural Development Achievement in Afghanistan ..........................................15

Rural Development Organizations of Afghanistan ...........................................16

Ministry of Rural Rehabilitation and Development .......................................16

National Solidarity Program ........................................................................16

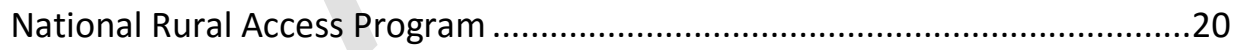

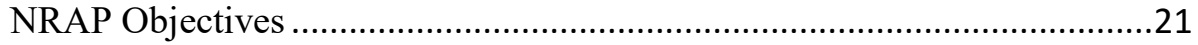

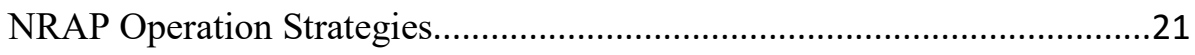

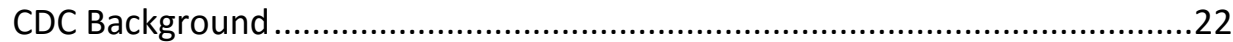

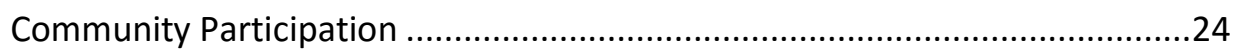

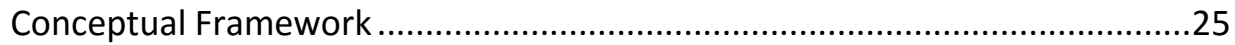

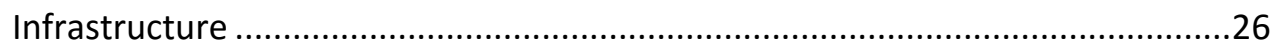

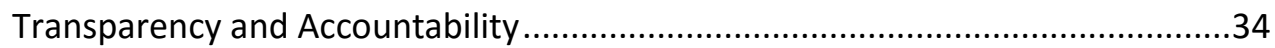

Provincial Development Plan Goals ................................................................36

Aid Effectiveness in Afghanistan ......................................................................38 


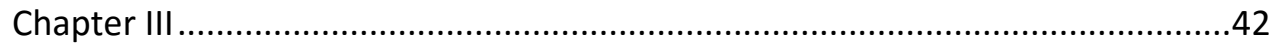

Research Methods .................................................................................42

Target Group and Sampling ............................................................42

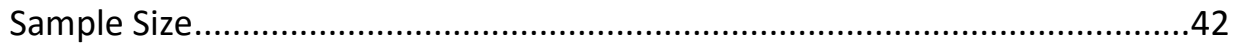

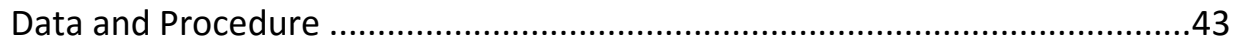

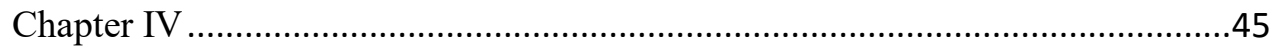

Data Analysis and findings..........................................................................45

Main Problem of Rural Development in Panjshir........................................56

Impact of Foreign Aid in Rural Development of Panjshir .............................62

Effect of Rural Development projects in Panjshir .........................................68

Main changes of Rural Development in Panjshir ..........................................71

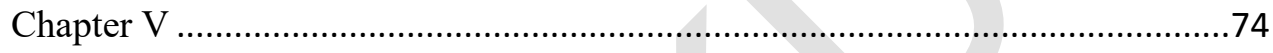

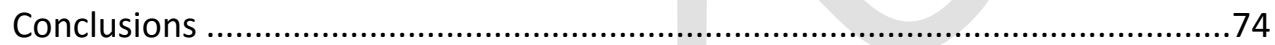

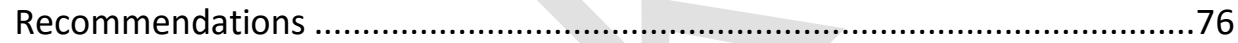

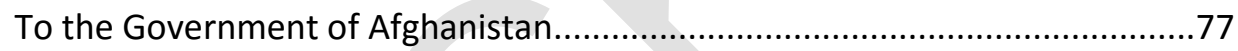

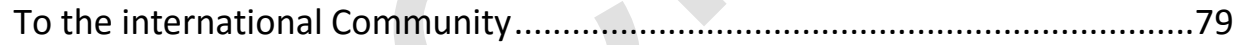

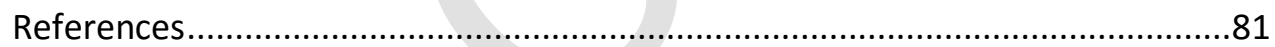

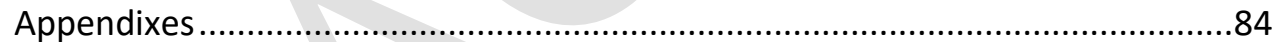

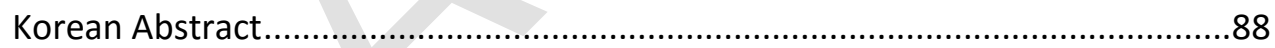


List of Figures

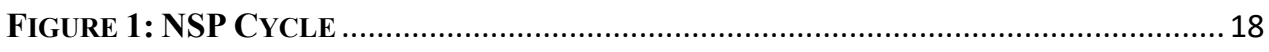

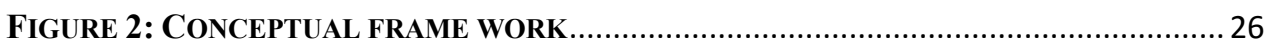

III 


\section{List of Tables}

TABLE 1: NSP III FINANCED AND COMPLETED PROJECTS 19

TABLE 2: NRAP ACHEIVEMENT IN RURAL DEVELOPMENT 22

TABLE 3: SeX TABLE

TABle 4: Does Afghanistan neEd MORE ForeIGn AID FOR ITS RURAL DEVELOPMENT?

TABLE 6: FOREIGN AID HAS BEEN USED PROPERLY IN RURAL DEVELOPMENT OF AFGHANISTAN SO FAR. $\quad 48$

TABLE 7: FOREIGN AID HAS BEEN USED IN PANJSHIR PROVINCE BASED ON UNDERSTANDING OF PEOPLE'S NEED. $\quad 49$

TABLE 8: FOREIGN AID HELPED THE PROCESS OF RURAL DEVELOPMENT IN PANJSHIR PROVINCE. $\quad 50$

TABLE 9: RURAL DEVELOPMENT SHOULD BE THE FIRST PRIORITY OF GOVERNMENT FOR UTILIZING FOREIGN AID.

TABLE 10: AID IS REQUIRED TO ADDRESS THE SHORT-TERM CHALLENGES AND SUSTAINABLE POVERTY REDUCTION IN THE PANJSHIR PROVINCE. 52

TABLE 11: AID IS CENTRALIZED AND TOP-HEAVILY FOCUSING ON KABUL AND OTHER URBAN CITIES. 53

TABLE 12: DO YOU BELIEVE THAT FOREIGN AID IS HELPFUL FOR THE DEVELOPMENTAL PROJECTS IN THE COUNTRY? 


\section{Abbreviations}

ANDS Afghanistan National Development Strategy

NSP National Solidarity Program

NRAP National Rural Access program

MRRD Ministry of Rural Rehabilitation and Development

GoA Government of Afghanistan

ODA Official Development Assistance

OECD Organization for Economic Co-operation and Development

DPs Development Partners

ADF Afghanistan Development Forum

MDG Millennium Development Goals

PRSP Poverty Reduction Strategy Paper

MoPH: $\quad$ Ministry of Public Health

MDGS Millennium Development Goals Strategy

MoICT Ministry of Communication and Information Technology

NGOs Non-Governmental Organizations

FPs $\quad$ Facilitating Partners (FPs)

MoPW Ministry of Public Work

NEEP National Emergency Employment Program 
ILO International Labor Organization

CDD Community Driven Development

UNFPA United Nations Fund for Population Activities

UNOPS United Nations for Project Services

UN United Nations

ANSF Afghanistan National Security Forces

CDC Community Development Council

PDCs Provincial Development Councils 


\begin{abstract}
The purpose of this study is to examine The Effectiveness of Foreign Aid in Rural Development of Afghanistan (A Case Study in Panjshir Province). More than 15 years of humanitarian, security and development aid and assistance has been provided by the international community and donor countries to the government of the Islamic Republic of Afghanistan. Through this, the country has improved and got a significant achievement in many rural areas since 2002.
\end{abstract}

The information in this research is extracted from primary and secondary sources of information. The researcher used books, journals, and research papers for collecting secondary information. For the primary source of information the main tool was survey questionnaire and personal visits with villagers in Panjshir province of Afghanistan.

The study affirms that foreign aid has helped to enhance the rural areas of Afghanistan, specifically Panjshir province. The province of Panjshir has significantly improved and developed in terms of economic and rural advancement. In utilizing foreign aid, the Afghanistan rural development organization has worked hard for the improvement and expansion of rural areas and rural people in the country. The achievement of rural development projects in the country is really outstanding through programs funded and supported by the international community including the National Solidarity Program (NSP) and National Rural Access Program (NRAP).Many bridges, roads, education centers and health care centers were newly constructed or rehabilitated in the rural areas of Afghanistan. As of 2014, a total of 1,400 km of roads have been paved, 1,600 bridges were newly constructed, and millions of labor days have been generated through the NRAP.

Key words: Foreign Aid, Rural Development, Infrastructure, Sustainability, Transportation, Agriculture, Security, Education, Health. 


\section{Chapter I}

\section{Introduction}

Afghanistan, officially named the Islamic Republic of Afghanistan, is a landlocked country in which $3 / 4$ of the country is covered in mountains. It is located within South Asia and Central Asia and has a population of approximately 32 million, making it the $42^{\text {nd }}$ most populous country in the world. It is bordered by Pakistan in the south and east; Iran in the west; Turkmenistan, Uzbekistan, and Tajikistan in the north; and China in the far northeast. Its territory covers $652,000 \mathrm{~km}^{2}$ making it the 41 st largest country in the world. (Akbari, 2016)

The country is divided in to 34 provinces, which are divided into a number of districts. The capital city of Afghanistan is named Kabul. The government and administrative system of the country is controlled by a president. The governance structure is separated into different levels including central government, provincial, municipality or district government and the local level government. (CIA, 2015)

Panjshir province is located in the central zone of Afghanistan and surrounded by Nooristan in the east, Kapisa in the south, Parwan in the west, Baghlan in the northwest Takhar in the north and Badakhshan in the northeast. The province covers an area of $3,531 \mathrm{~km} 2$. Nearly the entire province $(91.2 \%)$ is mountainous or semi mountainous terrain while only about $4.4 \%$ of the area is made up of flat land.

The province is divided into 7 districts. The provincial capital is Bazarak which has a population of about 15,593 inhabitants. (ANDS S. , 2007) 


\section{Research Background}

Afghanistan is one of those countries in the world in which most of the residents of the country still do not have access to any kind of basic needs and services. More than thirty years of war have destroyed and damaged the infrastructure of the country including education centers like schools and universities, health facilities, roads, electric dams and many other facilities. When the incidence of September 11, 2001 happened, many of the international actors came to Afghanistan to help the country in the process of development and rebuild the country's infrastructure system again. Many of the world's countries have turned their attention to Afghanistan to support and recover the country as a failed state to a self-sufficient Afghanistan. After the civil war, the country started to manage and emerge through a development process introduced in an international conference assembled in Bonn, Germany in 2001 to help Afghanistan for a better and self-sufficient country. The objective of the conference was to target the emergency needs of the country. Paving the way for new elections, there was a committee in Bonn conference that drafted the new constitution for the new government which took place in 2001. . (Akbari, 2016)

The purpose of this study is to examine the Effectiveness of Foreign Aid in Rural Development of Afghanistan (A Case Study in Panjshir Province). More than 15 years of humanitarian, security and development aid and assistance from the international community and donor countries has been granted to the government of the Islamic Republic of Afghanistan. Despite this, the country has not changed a lot in different sectors. The rural parts of the country especially has not been developed in the past 15 years. Also, infrastructure remains a challenge for rural Afghanistan as development was not sustainable. The government did not make them many facilities like roads, health care centers, schools and many other facilities. Aid from donor countries can help Afghanistan to prepare itself from a conflict and challenging country to stability, independent, secure and economically developed Afghanistan. 
In comparison to other parts of the country, Panjshir province of Afghanistan has not been developed and needs more work. To develop this province, we need to work with the villagers and the people to help the development projects in their hometown. (Waldman, 2008)

\section{Research Questions}

What is the impact of foreign aid in rural development of Afghanistan?

Does Afghanistan need more foreign Aid for its Rural Development?

\section{Significance}

This research will be highly beneficial to Afghanistan rural development. The researcher specifically focused on rural development in Panjshir province of Afghanistan, which can help the government rural administration offices in local and national level. The Ministry of Rural Rehabilitation and Development can use this research as a frame work for understanding the challenges and problems of the foreign aid to rural development in Afghanistan.

Objectives

- To find the impacts of foreign aid in rural development of Afghanistan.

- To know whether Afghanistan needs more Aid from the international community or not.

Scope of the study

This thesis writing aims to find out the impact of foreign Aid in rural development of Afghanistan and will focus on a case study in Panjshir Province of Afghanistan. Also, this study will focus on the problems of rural development in Afghanistan and the future challenges of rural development in the country. This thesis studies two indicators in determining the impact of foreign aid: agriculture and infrastructure. In addition, the methodology and size of this study is limited which does not allow for addressing the influence of other factors other than the two indicators which is mentioned above. 


\section{Chapter II}

\section{Literature Review}

Each and every word doesn't have one definition, also a definition for a word can be the idea of many scholars and philosophies, and here I also cannot give one definition for the word Aid. The word Aid can be defined as a term for the small and big value of the financial assistance which can be direct or indirect to the recipient countries and the poorest nations in the world.

Foreign Aid can be defined as a flow of technical and financial resources to the recipient or third world countries or to the poor and underdeveloped countries. The foreign assistance which is also called foreign aid, is the international allocation of budget, goods and services from the international communities and organizations to the poorer countries in order to help the population of recipient countries. The international assistance can be in terms of emergency cases or can be in terms of helping people economically, humanitarian and military services. The aid is usually committed with the interests from the donor and recipient nations or countries. The idea of foreign assistance might be changeable over the passage of time because the process of development in the developing nations and communities is not the same that's also changeable. (Totakhail, 2011)

Since the foreign aid is a voluntary assistance by independent nations, it is becoming slowly to the communities which can contribute with them to make an organized community by the help of foreign aid. The responsibility of a human is to contribute in proportion or more than an arrow to help the communities in their progress of wealth and bring them prosperity in to their life. Foreign assistance can become a silent weapon to control the poverty and eradicate the inequality as an international framework. The foreign aid is separated in two big categories which is humanitarian and non-humanitarian assistance. Humanitarian aid is an assistance which is provided during emergency cases or after the 
emergency cases to protect the lives, save human dignity and to improve the suffering lives in accordance to the humanitarian basics.

The Humanitarian assistance includes prevention of disaster, shelter facility, drinking water or clean water, food, health and sanitation. This kind of assistance helps the affected people to grant them a normal life back. On the other hand, the non-humanitarian aid includes the aid for development related issues, social issues and economic factors which have resulted from the disaster or emergency cases such as the debt relief scholarships and administration costs. (Totakhail, 2011)

\section{Foreign Aid History of Afghanistan}

The Afghanistan current situation is dependent on external aid not only because of three decades of war in the country. Even before the 30 years of war and conflict in the country, in the last two centuries the country's economy was not stable and sustainable. It was always not a sufficient economy to its population. The Afghanistan economy depends on the foreign aid. Foreign assistance to the country plays a pivotal role in the development of the country and the progress on the development projects of the country. The first foreign assistance to Afghanistan took place in the $26^{\text {th }}$ of January 1857 while the British company signed a contract between Afghanistan and the British India in the area because The British India was against the Persian violation in the area.

With the passage of time and changes in the political and economic situations, the amount of aid and degree of aid dependency has also changed in Afghanistan. "Although the mentioned financial assistance did not necessarily put Afghanistan in aid dependent nations' category, the country has rarely achieved fiscal sustainability even after it gained de jure and de facto status of state. (Raqeebi, 2013) 
The available data shows that after Bonn conference in 2001, the international community, especially OECD (Organization for Economic Cooperation and Development) countries, decided to demolish roots of terrorism and help the country by providing Foreign capital in the form of aid to take primary steps toward development and stability. Since 2001, Afghanistan got its legislative government and most of the other countries also became keenly interested to help the country to similar development goals. International community through the various international major "pledging conferences from 2002 to 2012 (Tokyo, Berlin, Paris, London, Kabul) which focused on Afghanistan have signed the agreement to provide development aid for Afghanistan" (Afghanistan Agreements, 2011). After the establishment of interim government, a total of 90 billion USD foreign aid was pledged from 2002 to 2013.

However, only 69 billion USD has been formally committed for the period of 2002-2011, and dual money disbursed is only 57 billion USD of the actual ODA from 2002- 2010. Most of these aids were spent towards huge projects on development and reconstruction of Afghanistan. These aids are divided in two major areas: 51 percent for security and 49 percent for development projects in other sectors (Infrastructure, Governance, Health, Education, Social Protection, Rural Development, Agriculture and private sector). Almost 30 percent of this has been provided through the Afghanistan's budget, but the rest of the 70 percent has been managed through the development partners (DPs). Since 2002, development budget of Afghanistan is 100\% dependent on foreign aid. (Ministry of Finance, 2012)

In December 2005, there was the establishment of Afghanistan National Development Strategy (ANDS), which was established in the Afghanistan Development Forum (ADF). From 2005, ANDS became mainly responsible for disbursing foreign aid in three main headings:

- Economic development and Social Development 
- Administration and good government, Rule of Law and Human Rights

- Safety and security

ANDS plans for every five years and it is working to reach objectives of MDGs (Millennium Development Goals). The other purpose of ANDS is to fulfill the requirement of PRSP (Poverty Reduction Strategy Paper) (ANDS G. o., 20082013)

Moreover, these aids are spent to reduce poverty, bring stability, increase healthcare, education, economic and security sectors related to ANDS and MDG's goals. There are many projects in progress to utilize these aids to achieve development goals and objectives in Afghanistan. To illustrate more, we can have a look in healthcare sector that has improved a lot especially in last 10 years. In the health sector, Afghanistan has improved and brought many facilities and services. The number of facilities are greater than before, from 496 in the year 2002 to more than 2500 in the year 2013.

The educated female health staff have also increased from $25 \%$ to $72 \%$. Incredible increase on the public finance sector revenue has increased from US $\$ 130$ million in the year 2002 to US $\$ 1.5$ billion. Currently, the GDP per capita and the human development indicators of the country has significantly improved. The Real GDP growth was $21 \%$ in $2009,8.4 \%$ in $2010,5,7 \%$ in 2011 and estimated $7.1 \%$ in 2012 which is in average 9.1 percent from 2003 to 2011. A balanced progress in education sector by the school enrollment for children age 712 from 37 percent to 52 percent are some good example in the achievement of development aids. (BankWorld, 2012)

As a result of foreign funds in the form of aid for development of Afghanistan, we can conceive increases in level of education, living standard, stability, constructions, and etc. All development in economics, politics and social sectors is because of foreign aid of international communities which are constructively started after Bonn conference in 2001 to rebuild Afghanistan. The 
most negative point and limitation are limited share of Afghan's government to controls and effective utilizing of these foreign aid. (Author)

\section{Rural Development}

Rural development is a procedure for improving life and is the way for having a modern community and good economy for remotely populated zones in a community or rural areas. The rural places are those kinds of places which from the viewpoint of geography are located on the outside of towns and cities. The rural areas are also those places which are not counted as an urban place in terms of geographical theories. The rural areas can also be defined as those places which the population, housing, and the land is not counted with the urban areas. Simply, we can define the word rural as those places which are not measured as urban places. The rural areas in a country are those places which are not developed as cities and towns in the country. (Malcolm, 2003)

The purpose of rural advancement is generally to improve the standard of lives and economic quality for the people whom are living in the remote areas. Traditionally, rural development is focused on using natural resources which found in the rural places like agriculture and forest while the variations in production of global system effects the lives in rural areas that's why urbanization of rural area are strongly affected by changes in the world system of urbanization. The World Bank defined rural development as a process to improve the life of villagers economically and socially. The purpose of rural development administration is to formulate and implement the programs which can change and improve the life style of the villagers. (Malcolm, 2003)

The rural development in Afghanistan have many challenges, the main challenges in rural development of Afghanistan is demographic changes and rural movement. The rural development in the country faces some challenges due to the development of other remote rural areas of Afghanistan. The migration of young and educated people is also challenge for rural development in Afghanistan 
because these young generations can help the process of development in their places. The young and well educated people of rural areas can help to implement the policies in the rural Afghanistan but since they are moving to the urban places that's why the problem of rural areas are still remaining as a challenge for development. Implementation of rural development policies and strategies can help in advancement of the rural places and of course it will bring many facilities and opportunities in the area. Rural development is a priority for the Afghan government and it is the responsibility of rural development organization such as ministry of rural development of Afghanistan (MRRD). (Raqeebi, 2013)

MRRD has developed many development programs for rural improvements such as NSP and NRAP. The NSP stands for National Solidarity Program and NRAP stands for National Rural Access Program. These programs were established in 2003 to help the procedure of the rural development in the country and to support the rural communities to improve their capacity and prioritize their emergency needs as well as to know the problems of rural areas of Afghanistan. NSP is the largest rural development program in Afghanistan, since the program has been established in 2003. The aim of the NSP was to empower the community development councils for having a better life. They were created to form and reestablish the rural substructure of the villages and to support the community members. (NSP, 2015)

\section{Challenges of Rural Development in Afghanistan}

Millions of dollars have been donated to Afghanistan from the international communities to the government of Afghanistan to rebuild the country and make it a stable place for its residents and peoples of the country, the aim of the foreign assistance to Afghanistan was to developed the economic and to make an independent country but unfortunately the following challenges have strongly affected the development process in the country. 
Security is a major challenge for Afghanistan development, many people in Afghanistan and the international community believes that security is a big challenge in the country that's why bringing stability to Afghanistan is problematic, due to security challenges Afghanistan government is failed to bring changes in the country, the assistance of the foreign donors to the country during the past decades to the country is a big achievement for the new democratic government of Afghanistan, not secure and stable situation for the country is still a big problem which have affected the people's lives and makes the country unsecure to its resident and foreign investors. There are some reports about the country's security problem and the foreign assistance to Afghanistan which billions of dollars from the international friends has failed in the country because of insufficient capacity and the influence of political giants and the irresponsible commanders in the country, these people makes a lot of problems for government and the international assistance to country, the bad security conditions in Afghanistan and the antigovernment groups have caused that foreign assistance has face many challenges, they were the people who have had their interests in the developmental projects without their influence that is almost impossible to complete the projects in the provinces, these political and irresponsible giants are the problem for the government development projects and the international assistance to Afghanistan.

Because of these groups and the bad conditions of the security in country billions of dollars were failed to help Afghanistan in the development of the rural areas especially in northern and eastern province of the country, this kind of problems will make Afghanistan in the long term still unstable also unsecure place for its residents and the international community, if there is not strong capacity of management to control the foreign aid the country will remain as it was. (Williams, 2011)

The security is a major and fundamental problem for Afghanistan to achieve stability and a progress in the development process of the country. This problem is not only belongs to the security forces to bring peace and stability 
without the support of the people and the international assistance, the responsibility of the Afghanistan government is to fight against the those groups who are making trouble for the government and people, but people shout help them in bringing prosperity and peace, the peace in the country without justice and strong leadership and management systems is impossible, to bring peace and sustainability in the country this is important for the afghan government to element illegal armed forces whom making challenges for the people and government. Government of Afghanistan and the international community should make sure to improve the security organizations for a better future and a peace country. (Williams, 2011)

The international community should not leave the afghan security forces alone, they have to support them continuously until they can control the whole country by their own power, and this kind of support makes the afghan security forces strong and stable. By the withdrawal of international security forces (ISAF) an NATO whom were led by the United States, the support to Afghanistan security forces is an essential job of the mentioned international security forces and the international community especially United States because they were the partner of afghan government to bring peace and prosperity in the country, since the international community and United States are committed to help Afghanistan in order to bring sustainable development in every sector of Afghanistan, they are committed to support Afghanistan until a strengthen and stable Afghanistan. The international friends should support the Afghanistan national security forces to develop their capacity, the afghan armies are in fight with hidden opponent which is terrorism, international friends should help the afghan security forces to element this illegal armed groups in the country, as I mentioned above the NATO and ISAF is committed to help Afghanistan security forces because alone they cannot fight against these terroristic groups, they the enemy of the whole world not only Afghanistan. The ISAF forces reconstruction team are helping the provincial development around the country, they were committed to keep this support and improvement of the security sector in the country. If the international commitment remains like this for sure the country's stability and sustainable 
development is grantee in every sector especially security which is a major problem of Afghanistan in terms of development. (BBC, 2008)

\section{Weakened and Incapacitated Infrastructure}

As I have mentioned above that security is the problem for Afghanistan development project will not forget that weak infrastructure is another challenge for the rural development of the country and has effected the contribution in the development projects in Afghanistan. In a country like Afghanistan that doesn't have good roads and high ways to carry out the goods for the development projects how can be the development process speedy and well maintained. there is also lack of airports in the country to carry out the goods for the development programs, we need to build our infrastructure such as roads to supply the basic needs of the development projects, transportation is very important in building the infrastructure of the country that must be reconstructed first then any other development programs. Security remains a major problem for every individual project in the country, supplying goods to other provinces needs security attentions without security guards it is impossible to supply the project basic needs, during the war in the country many places have been covered by mines so that places needs to be cleared first then we can go forward for the project implementation and the reconstruction of the rural areas in the country. Making networks with people is also hard in the local communities, if you want to construct a project in the provinces you need to have strong network among the people or you have to hire a social worker for this job and also you need to make relations with provincial and government officials. This kind of problems are always the obstacle for the development projects in the country, people find this, as a major problem in the country to carry out the projects and makes it ready for the operation. (Raqeebi, 2013) 


\section{Corruption}

Generally corruption is one of the major problems in the country which is an obstacle for the development projects and it needs to fight against it in a very large concept to eradicate it from the society with its elements, as of 2015, fifty percent populations of the country has paid bribe for their legal requests, many government officials are corrupted, for each individual request they want to influence in your job and responsibility so needs to fight against corruption in the country, the total amount of bribe which was asked during the last 5 years creates the amount US\$ 4.00 billion dollar. This is research has took place in recent years in the country, during the Taliban regime in the country there was an equality between people and government, everyone had an equal rights for its requests, during that nobody were able to ask for bribes and making trouble for the people, only there was no progress in economic section and any other development projects, while after the Taliban regime in the country people were very and hoping a democratic government, because all people were about an transparent government unfortunately that doesn't happened. (Raqeebi, 2013)

Unfortunately the gap between people and government has been improved due to corrupt services and corrupt employees, at all there is no good relationship between the people and the government, people are now hopeless to finished the legal requests on time in the government organization because of corruption, they can't finish their legal work in transparent way and under the rule of law, people are not thinking for good government in the country they know that the government officials are corrupt and they are confident on the government has been decreased to its lowest point, since there are some people whom are thinking and hoping for the new president who has took the power in 2014, they are still hoping him to bring prosperity and sustainability in the country and can change the government situation and peoples too but this is also a reality that the new government couldn't change the peoples mind to its positive point and people still remain hopeless, hope to see the country one day stable and transparent. (Raqeebi, 2013) 
Corruption in the country is a big challenge for the development projects also to be mentioned that corruption is a problem at all levels and have a big impact on the development, the weak government institutions and lack of good governance for the financial issues and having parallel institutes for development projects, sub contraction of big projects in the country is major challenges for the development projects and the usage of foreign aid, I would not to forget about no transparency and lack of information sharing with the people also effected the foreign aid to be used in an transparent way. (Raqeebi, 2013)

There are some other factors as well that foreign aid effectiveness is limited, the political and security priority for the donor countries, they wanted to use their aid for the political and security problems first and then they will work for the development projects as well, they have never thought about the Afghan people priorities, if the foreign friends wants to help the people they have to think about priority from the people, by this they can achieve their goals of foreign aid as well as their will be a sustainable development projects, the international colleagues wanted to reduce the poverty in the country and help the afghan communities to bring peace and prosperity in the society which itself will make a big impact on the self-help, lack of connection and networks with the afghan provincial community council is another problem for the foreign aid to use it in proper way, they have never been asked for their needs, this case is very true about women in Afghanistan, they are the people whom will not be asked for single issue in the development projects, the foreign assistance should target the rural areas in Afghanistan and their needs, the rural area in Afghanistan is almost $80 \%$ which is a big percentage, so we need to work a lot in the rural areas, the foreign assistance should be used based on the peoples need and this is a better way to get a better result in the rural communities, we have to be connected with the local communities in the countries, this is a way that we can use the foreign aid equitable, the Afghanistan government and the foreign colleagues should focus on how to make relationship with local people for better implementation of the rural development projects. (Raqeebi, 2013) 


\section{Rural Development Achievement in Afghanistan}

The achievement of rural development projects in the country is really outstanding, and rural development of the country has been significantly improved, the Afghanistan rural development organization have tried a lot to work hard for the improvement of rural areas and rural people in the country, many bridges and roads have constructed in the rural areas, as of 2014 the total of $1400 \mathrm{~km}$ roads, 1600 bridges newly constructed and millions of labor days have been generated by NRAP rural organization, still they are working for the development of rural areas, the mentioned rural development organization is committed to achieve the numbers above as of 2019 double.

This is to be mentioned that NRAP is working under to ministries in the country which both of them have achievements in rural areas, the NRAP/MoPW has completed the same projects of construction of new roads and bridges, the NRAP/MoPW constructed the total of $1200 \mathrm{~km}$ roads, 1500 meter of bridges and the progress is still ongoing for the projects. (MRRD, 2016) 


\section{Rural Development Organizations of Afghanistan}

\section{Ministry of Rural Rehabilitation and Development}

Ministry of rural rehabilitation and development (MRRD) of Afghanistan is founded to establish rural development organization across the country and work for the rural of Afghanistan since the majority of the country is rural areas, the ministry of rural development have its sub offices in all 34 province, the ministry of rural development programs and sub offices have the responsibility to work for the social and financial improvement of the rural areas in the country, the rural development programs and sub offices in the provinces is financing by both MRRD and the international colleagues. (MRRD, 2016)

The objective of MRRD is to eradicate the poverty in the rural areas of Afghanistan, the ministry is committed to help the poor rural people to improve their lives in the communities, the strategy of Made in Afghanistan is a developmental strategy to help the poor people in Afghanistan, the mentioned strategy aims to target the small and medium enterprises in the rural areas of Afghanistan, also the strategy aims to achieve the goal of National Development Strategy (ANDS) which was about the elimination of poverty in rural areas and all over the country, the strategy for the development of the Islamic Republic of Afghanistan is committed for sustainable development and to achieve the UN's Millennium Development goals. (MRRD, 2016)

\section{National Solidarity Program}

The ministry of rural development of Afghanistan has established national rural development programs to achieve its rural development goals, one of these programs in the ministry of rural development is National Solidarity Program (NSP). The mentioned program aims to work with the local communities to prioritize, develop and identify the projects in the community levels, the NSP 
aims to manage, design, plan and observe the development projects in the local level of the country, and NSP is responsible to work along with the local communities for making the decision of rural development projects also to empower the local governance, having good local communities is a grantee for the human security challenges, the program is supporting the all the local communities across the country and also the poor people in the villages. NSP promotes to help the local communities whom they can make decisions and contribute at all levels, the local communities in Afghanistan have election process to choose one person as a leader of the community, the leader is responsible to inform the people and government for needed emergency cases and other rural development projects, indeed the role of the community leader is like a bridge between government and the villages. (NSP, 2015)

In 2003, the Afghanistan Rural Development ministry with a strong support of the World Bank also a broad range of other international donor agencies, initiated the National Solidarity Program (NSP). NSP was a Community Driven Development (CDD) program designed to provide public services and development opportunities to rural communities and to form local representative institutions called Community Development Councils (CDCs). Between 2003 and 2010, NSP implemented activities in approximately 23,000 communities throughout Afghanistan. In 2010, the program entered in its third phase, which aims at covering approximately 17,200 newly included local communities for a first round of block grants and approximately 10,500 already included local communities for a second round of block grants. Activities are implemented on the ground through Facilitating Partners (FPs), NGOs or International Organizations NSP is the largest development program in the country, with donor contribution totaling more than US $\$ 1.5$ billion as of 2010. The proposed budget for NSP-III from September 2010 to September 2015 is nearly US $\$ 1.5$ billion, or roughly US\$300 million per year. This proposed annual budget represents about 20 percent of the country's total annual development budget. A largely unasked and unanswered question regarding NSP is the cost of maintaining subprojects built over the past 6 years. Although many of the subprojects constructed require 
little to low maintenance which can be performed and funded by communities, others, such as tertiary roads, water supply networks, and micro hydro plants require often costly or technically complex labor or replacement parts. (NSP, 2015)

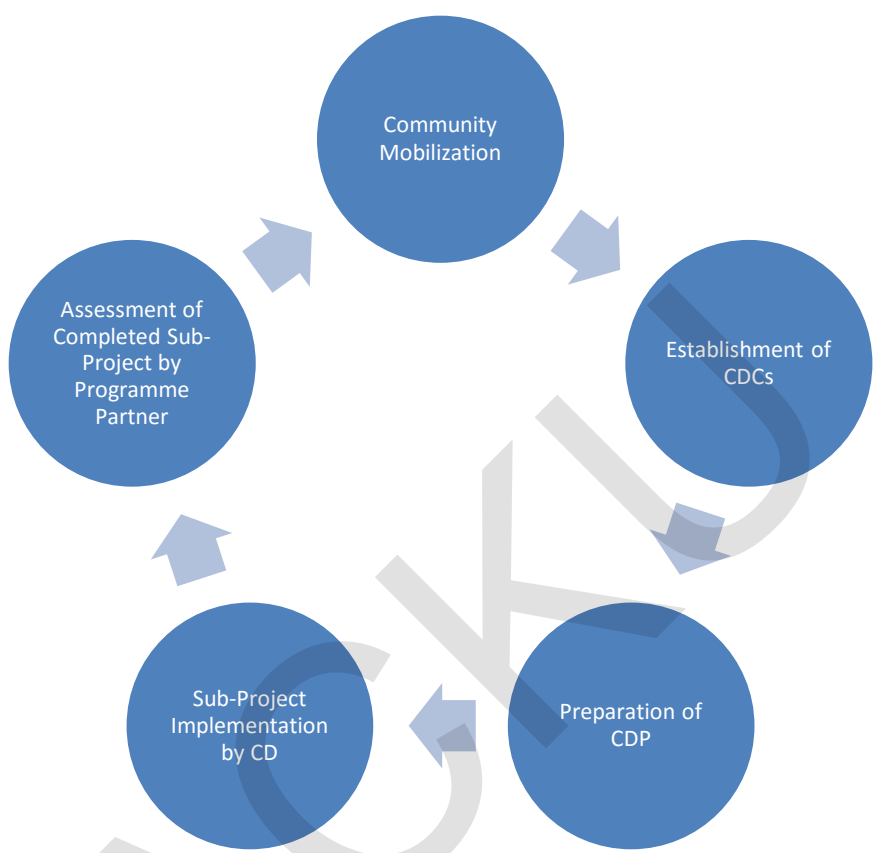

Figure 1: NSP Cycle

Source: (NSP, 2015) 
Table 1: NSP III financed and completed projects

\begin{tabular}{lllll}
\hline NSP IIIA\&B & \multicolumn{2}{c}{ Financed \& disbursed } & \multicolumn{2}{c}{ Completed } \\
\hline Sector & Projects & $\begin{array}{l}\text { Value US\$ } \\
\mathbf{m}\end{array}$ & Projects & $\begin{array}{l}\text { Value US\$ } \\
\mathbf{m}\end{array}$ \\
\hline Transport & 7,950 & 190 & 3,052 & 71 \\
Water & 6,237 & 116 & 2,322 & 39 \\
Irrigation & 6,102 & 135 & 2,156 & 45 \\
Power & 1,246 & 37 & 550 & 14 \\
Education & 602 & 22 & 39 & 2 \\
Health & 56 & 2 & 6 & 0 \\
$\begin{array}{l}\text { Rural } \\
\text { Development }\end{array}$ & 3,028 & 71 & 917 & 19 \\
Livelihoods & 89 & 1 & 62 & 1 \\
\hline Totals & $\mathbf{2 4 , 9 5 0}$ & $\mathbf{5 7 3}$ & $\mathbf{9 , 1 0 4}$ & $\mathbf{1 9 2}$ \\
\hline
\end{tabular}

Source: NSP MIS (as of 30th April 2014, exchange rate 50 AFS: 1US\$)

The Table above shows the national solidarity program projects which have been financed and implemented in all over Afghanistan, the table indicates that how many projects have been completed and with how much value in US dollar, the table also shows different types of projects implementation process from the national solidarity program. 


\section{National Rural Access Program}

Originally the national rural access program is created as national emergency employment program, this rural development program is established in 2002 to make facility and to improve the rural areas, survey was done in 2005 by, World Bank, ILO and the Afghanistan government to know about the emergency needs of the rural areas and to develop the rural areas in a very transparent way, at the starting point of second phase of the NEEP program was renamed as National Rural Access Program (NRAP), the main objective of the program is to build new rural roads and making a network in rural communities of Afghanistan, as the slogan of the program is; NRAP connects rural area of Afghanistan, it means they are focusing on the rural roads, bridges and other rural development services. (National Rural Access Programme, 2016)

The NRAP aims to make sure that every village in the country has been served equally and access to the basic needs and facilities, the NRAP programs objective is to bring facilities for every individual village and community in the rural areas of Afghanistan, that they can manage their daily life, according to the commitment of the program that infrastructure should be the first priority in development of the rural areas in the country, they want to build and provide equal and high quality of rural basic needs such as roads, bridges, schools, and providing clean drinking water, by construction of the above facilities in the rural of Afghanistan, definitely it creates job opportunities for the villagers, which will affect the rural people income as well. (National Rural Access Programme, 2016)

The objective for NRAP rural development program is to create rural road connectivity in the villages of the country and make many infrastructure services for the rural of Afghanistan, like educations centers, healthcare centers and access to markets, also the aim of the program is to create job opportunities for the rural people which the can enhance their daily life capacity. The NRAP program wants to improve the capacity of the rural communities that they can manage their routine tasks in their villages. (NRAP, 2014) 
NRAP Objectives

- Creation of good quality roads in the rural areas that can connect the rural communities to each other and to connect the rural people to access the public services like educations centers and healthcare centers.

- To create Job opportunities for the rural people, which is very important point in the development process.

- To improve the local communities capacity and the private sector, which they can continue the development process in the villages and to deliver job facilities in the communities. (NRAP, 2014)

\section{NRAP Operation Strategies}

- NRAP is a dual program which is implementing its strategies under the Ministry of Public Work (MoPW) and the Ministry of Rural Rehabilitation and Development.

- Under the supervision of the two ministries, UNOPS is in charge for conducting the projects works with private sector and local communities, also the UNOPS is responsible to give and support technical advices for the program to implement its strategies and to achieve its goal of development, which is the high quality roads to connect villages to each other, will to forget that UNOPS is supporting the capacity building unit as well. (National Rural Access Programme, 2016) 
Table 2: NRAP Acheivement in rural development

\begin{tabular}{|l|l|l|}
\hline No. & Activity & Total \\
\hline 1 & KM of road rehabilitated & 46,850 \\
\hline 2 & No. of bridges completed & 116 \\
\hline 3 & RM of bridges completed & 3,450 \\
\hline 4 & $\begin{array}{l}\text { RM of structures (culverts, retaining walls, cause ways, etc...) } \\
\text { completed }\end{array}$ & 114,890 \\
\hline 5 & KM of road repaired under emergency maintenance & 566 \\
\hline 6 & KM of road cleared of snow & 9,054 \\
\hline 7 & KM of road under routine maintenance & 3,274 \\
\hline 8 & KM of road under periodic maintenance & 502 \\
\hline 9 & Labor days generated & 9.7 millions \\
\hline 10 & No. of villages connected by the program & 12,922 \\
\hline 11 & No. of districts covered by the program & 315 \\
\hline 12 & No. of provinces covered by the program & 34 \\
\hline 13 & No. of population served by the program & 8 million \\
\hline
\end{tabular}

Source: (NRAP, 2014)

The table above shows the National Rural Access Program achievement in rural development of Afghanistan which indicates the achievement of how roads and bridges have been newly constructed and rehabilitated in 2014, the table also show that millions of labor days have been generated for rural people of Afghanistan.

\section{CDC Background}

Since the NSP has launched in 2003 the community development councils were a part of the National Development Program, to enhance the community development projects in rural parts of the country, NSP is the programme which is fully supporting the community development councils, the responsibility of the CDCs are to know their needs, to choose their community leader, to make decisions with local government and consult them for a better implementation of the development projects. As mentioned above that NSP is established as a programme to prioritize the basic needs of the rural areas for the 
government of the Islamic Republic of Afghanistan with full support for rural development projects from World Bank (NSP, 2015).

The NSP was funding from different finance resources like WB and many countries to enhance the Afghanistan rural communities for reduction of poverty in their villages and to help them in local governance which is called Community Development Councils CDCs. The community councils are established in all 34 provinces of Afghanistan to contribute and makes sustainable development resources in the community and villages level. (NSP, 2015)

The process of establishing a Community Council is using the votes from villagers to choose their leader through a transparent and secret way for making a local governance, after that the CDCs are leading their communities for a better relationship and network with the government and donors, the CDCs are those people whom they making important decisions what should the priority for their village, planning of community level development plan is a part of their job, what should be the priority, this the CDC who is making the decisions for the prioritization process. (NSP, 2015)

Then they are going to make a proposal for development projects in the provinces, the proposal were reviewed and approved by NSP, in each project the net amount of USD 60000 is directly allocated to the CDCs, the local Communities are asked to make sure that is contributed at least 10 percent among the villagers. Since this process of the CDCs are enhancing the local people in Afghanistan local areas, the process is technically observing by the international colleagues and donors, the aim of the CDCs are to improve people's life in the rural community at all 34 provinces of Afghanistan, the CDCs with the value of shared visions they have to make equal priority for every single village in the province, and they have to bring sustainable development in the local and rural areas of Afghanistan. (NSP, 2015) 


\section{Community Participation}

In the past one decade the local communities were greatly on the top focus of the government to improve them in order to use their local resources and to participate in the rural development of Afghanistan, also the objective was to improve the level of local people lives standards. Why the local communities were on the top focus of the government because they know their problems in the local level and can utilize the fund well, also they can prioritize the basic needs of their own community, they can look back to the important solutions for a problem in the communities, they are the only people who knows the culture and the behavior of their people, they can easily find solution for a local problem, the local community participation have a big impact on the gap between local government and communities.

Community participation will bring development to the local lives and people, it is possible to happen every day a new improvement in the local level and decrease the gap between development and local standards of living, the communities in the local level focuses on the empowerment of the people to participate in the development projects for getting better result in the future, the communities are trying to build local people capacity and educate them to know how projects are important in their villages, how kind facilities will be brought to them by implementing the development projects in local levels, encouragement of villagers to participate in the development projects is the important part of the community participation, this can be a principle procedure to take action for the community improvement and development, community development will not be achievable unless if there is no coordination among the villagers and local communities, making a network between the villagers and local communities is an improvement machine for sustainable development. Community development should address the peoples need or the development projects must be implemented based on the people's need, otherwise we cannot get the expected results from the development projects. (NSP, 2015) 


\section{Conceptual Framework}

The following frame work is designed by the author based on his understanding from the rural communities in Afghanistan especially in panjshir province of Afghanistan, that how the local communities should work for the development of their province, this framework is related to the rural development and presenting the importance of provincial communities in the rural areas of Afghanistan, need assessment means that how the local people are dealing with their basic needs, how they are solving the problems in the community, like economic problems, social problems and agriculture problems, it all needs to know about it, this procedure can really help the local governance, international organizations, and other local services organizations, the mentioned organization should know how to deal with problems in local levels, need assessment is the key for success and helping in the villages.

NSP Afghanistan is a national development program under the ministry of rural development (MRRD) apart of other tasks, NSP deals with the local communities to solve the problems of rural areas in close coordination of local communities, the objective is to improve the local communities whom can enable them self for self-help and self-reliance, they have to pay attention to those problems in the local levels which the residents are faces every day also they have to identify the local resources for the communities basic needs, which is really needed to solve the problems that are a challenge for the villages and villagers.

Local communities and rural people should be encouraged to take part in decision making and prioritizing their local issues, the participation of the local people is very important for the development of the villages, they have to take part in the process of their village issues because they are the only people who better knows about the problems and solutions in the community, active leaders are important to play role model for the villages encouragement, he/she must be the one who can manage, mobilize and move forward the community development projects ahead, the role model should played very well to take place 
for the development of the communities mobilization process. The role model should be an example of problem solution in the community mobilization.

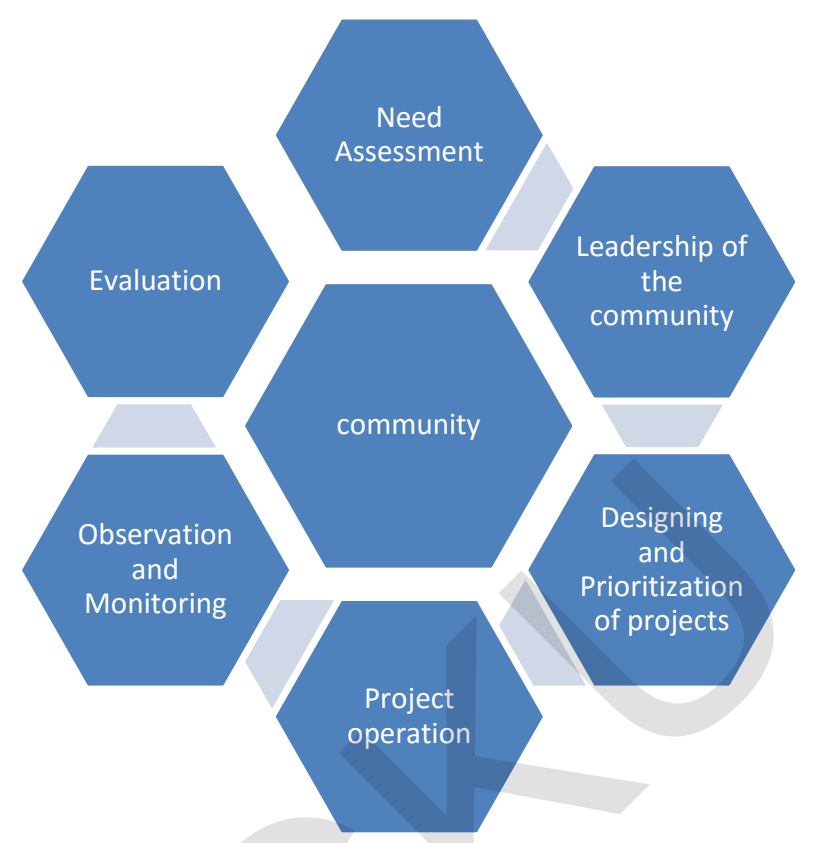

Figure 2: Conceptual frame work

\section{Infrastructure}

The system which is going to serve the country's economic system, or a serving system in a factory and business is called infrastructure, this kind of serving system can be in the country, city or a town, which includes all the services to improve the economic system in the country. The infrastructure is included with all the facilities which is really important for country or city development, such as roads, bridges, tunnels, education system like schools and universities, healthcare centers, agriculture, telecommunications, clean drinking water and etc. all this facilities should be technically supported by government to get a better result. (NationalAcademyPress, 1987) 
Infrastructure is a system which is providing the communities basic services or the infrastructure is defining as the hardware of a community to serve the people and community economic system, the infrastructure is strengthening the social lives system to live with a better live standards. In literature of English the word infrastructures is used since 1887 while the history of the word infrastructure in French goes to the end of the $19^{\text {th }}$ century and is at least from 1875 , the word infrastructure basically means fixing the fundamental of any operating system. (NationalAcademyPress, 1987)

\section{Education}

The Afghanistan government strategic vision is to provide quality education facilities for all Afghans all over the country regardless of the gender, economic situation, social situation, religion status, and regardless of any other superiority like ethnicity or the origin, the government aims to provide equal education facilities all over the country, access to better education is the right of every one in the world, to have better knowledge and skills you will be able to manage your life better, the high level of education employees are the long term goal for the government of Afghanistan to develop the socio economic advancement. (ANDS G. o., 2008-2013)

Education will bring prosperity to the country and all nations in the world and will enable people to understand better a long side the communities, foreign assistance to Afghanistan from 2001 has improved the education system and a brought significant changes in the education system of the country. At the begging of 2001 and before that, there was no good education system and less students were enrolled in schools and universities, but now there are millions of students going to study in the public and private schools and universities all over the country. Especially during the Taliban regime there was no progress in the educational sector, I am one those students who have studied during that regime as a live example I can say that education sector was totally destroyed by the Taliban regime, there was no modern subjects during that time, they were all focused on the religious subjects, none of the female students were allowed to go 
school and study, but fortunately after the transformation in early 2000, many school and universities were reconstructed and renovated by the assistance of foreign communities and new hope has been started in the education sector of Afghanistan. (Adina, 2013)

By the way in 2015 more than 10 million students were registered to study in the primary, secondary and high schools, as matter of fact one third of them were female students which is a great achievement in the education sector, there are more than 100000 thousands students, together male and female were enrolled to the higher educations, many schools and universities in both public and private sector are newly built and thousands of students are studying there. (Adina, 2013)

The mission of the ANDS to the health sector is, to improve the quality of the health care system in the country and bring quality health services for the people of Afghanistan, the Afghanistan ANDS strategic plan aims to support the afghan health care organizations and to achieve the MDGs goals, the health care organization in the country was not so good and neither it is not which can serve people in terms of healthy life styles. The assistance of the foreign colleagues enable this sector to present good services for the country's resident but still that is not satisfactory it must be supported to improve more. (ANDS G. o., 20082013)

The situation which is now on going in the country is so bad and is very poor in terms of presenting the health services for the people, the health pointers are very near to the last point of international indexes, and life hope is very poor, many of the new born babies are dying because of low health services, death rate is so high and there is tremendously a high frequency of malnutrition in the country. (UnitedNationsDevelopmentProgram, 2013)

There is some achievements in the health sector of Afghanistan which will be pointed bellow, the following improvements in health care centers has been achieved in recent years. 
- The primary health care facilities has been improved and expanded. The rural residents of the country are happy for the recent health care services, in 2002 there was less than 9\% improvement in the health sector while it is increased to $80 \%$ in 2008 .

- The female doctors in the health sector is increasing day by day. At least there is one female health consultant, female medical doctor or specialist in each medical centers. The number of female doctors were increased from $25 \%$ in 2004 to $80 \%$ in 2008 .

- Improvement of rural health care services, like there is new family planning between the married women in rural areas of Afghanistan.

- Improvement in child vaccination system in rural areas of Afghanistan from $57 \%$ to $70 \%$ in the years 2003 and 2008 .

- The child mortality rate decreased to 130 per 1000 lives in the year 2006 in comparison to the years 2001 and 2002.

- Life expectation has been increased up to 20 years since the life expectation was 44 years in year 2002 but it is increased to 60 years.

- The underage death rate is decreased from 170 to 95 per 1000 lives in the births live.

- The basic health care services has been improved, while the number of primary health care center in 2002 was 498 but fortunately this number is increased to more than 1970 in 2010. (Ministry of Public Health, 2013)

Using of foreign aid to improve the health care system of the country by the ministry of public health is understandable and successful, the health care sector has been improved in the recent years due hard work and foreign assistance by the international communities to Afghanistan, nearly all the health care system was broken because of more than thirty years of war. Today by the help and assistance of the foreign friends the health system is almost $80 \%$ repaired and can provide good services to the people of Afghanistan, especially women and child health care system is improved they can easily access to basic health services across the country. (Ministry of Public Health, 2013) 
The thirty years of war in the country has destroyed the transport system in the country, many of the city roads and highways has been damaged due to the ruinous war in the country, it was really difficult to travel to other provinces because of bad roads which it was full of dangers, making roads is very important in the country, roads are the first needs of making networks in the communities and provinces, having good roads can provide access to health care centers, education centers and markets. (RailwayGazette, 2011)

When the new government has started in 2000 after Taliban regime, makings roads were the top priority of the Afghan government to connect provinces to the capital city Kabul, reconstruction of the highways can provide more facilities for the government to implement their developmental projects in other provinces of Afghanistan. (RailwayGazette, 2011)

Many of the highways in the country were reconstructed by the help of foreign assistance to the Afghanistan government, the cities roads and highways projects implementation plans were technically and financially supported by the international community. But unfortunately due to the irresponsible armed groups in the country the highways were destroyed by the road side mines and bombings. The Afghanistan railways reconstruction have been started, in the different regimes of Afghanistan the railways have planned to start the construction process but it doesn't completed, so that is why Afghanistan is without railways in the area, fortunately in the recent years Afghanistan has started the planning of railways to build railway for the purpose of business with the foreign countries such as Uzbekistan, fortunately this railway project has been completed and inaugurated by presidents of both countries Afghanistan and Uzbekistan on the day of $29^{\text {th }}$ November 2016. (RailwayGazette, 2011)

The plan is to continue this railway until capital city Kabul and also other big provinces of the country. The Amu Darya River Bridge has complete and connected the two countries of Afghanistan and Tajikistan which is an achievement for the government of Afghanistan in the era of transportation. The Amu Darya bridge project has been completed by the help foreign aid to 
Afghanistan, the Amu Darya Bridge is financially supported by the United States of America and Norway to complete and restore the bridges for improvement of two business between Afghanistan and Tajikistan. (RailwayGazette, 2011)

Afghanistan is one those countries that it doesn't have good airways system, the first national airlines were created in 1955 which before of this date there was no airlines in the country, the Ariana Afghan Airlines is the first national airline in the country to serve the people of Afghanistan, the mentioned airline was the safest, valued and important airline in the region that people were served by that. (MoTCA, 2013).

Since the country was on the war in past three decades so the most infrastructure system is damaged and destroyed, due to this conflict in the country the Ariana Afghan airlines was also not able to continue its services in the region and to the people of Afghanistan, during the war Afghanistan has lost its all airport services all over the country. Since the new government aims is rebuild all the infrastructure system which is destroyed in the past decades of war, building airports is one that infrastructure, when the new government have started in 2000 the afghan airlines restarted its flights to the most Asian countries, and all over the country. The restoration process is going to be implemented by the help of international communities it means all this projects will be financially and technically supported by them, now a days many of international airlines are flying across the country's sky many Asian countries which is a significant achievement in terms of Afghanistan air transportation system. Now in Afghanistan there is more than four major airlines whom are serving the air transportation in the country, Afghanistan have four international airport which are in the big cities of Afghanistan such as, Kabul, Kandahar, Mazar and Herat international airports and it expected to increase the number of international airports for better serving of the people. The mentioned airports were damaged during war in the country but fortunately by the technical and financial support of the international communities with close coordination of the Afghanistan government these airports were reconstructed. The Kabul international airport is 
expanded in 2009 while there was only one terminal but now it have domestic and international terminals. (BBC, 2008)

Since there was domestic airlines in the country to serve the people beside this fortunately now there is international airlines as well such as Fly Dubai, Air Arabia, Emirates, and Iran airlines to fly between Kabul and other countries. (ArabNews, 2013)

The Afghanistan telecommunication sector was also very poor in the past decades since the country residents was not able to contact each other over the phone easily, in early 2001 while the new government has started the telecommunication was significantly improved. In the year 2002 there was a number of people whom were able to make phone calling and connect each other, before 2002 there were only 12000 people who have had telephones in capital Kabul city, there was no mobile phones and internet facilities in the early 2001. (WorldBank, 2013)

The ministry of communication and Information Technology (MoCIT) mentioned in a report that almost $85 \%$ residents of the country are covered by mobile services in the year 2012, the mobile phone services in the country is providing by private companies such as Afghan Wireless Communication Company (AWCC) which is the firsts mobile phone company in Afghanistan, Roshan, MTN and Etisalat companies. Mobile services in the country is extremely improved due to their wireless production services to the people, according to the report of MoCIT there are 18 million mobile subscribers across the country, for the first time Afghanistan was able to access and control the internet in 2003 , almost $85 \%$ population of the country is covered by mobile phone services by private telecommunication companies. There is many internet services providers in the country to make internet facilities for almost 1.2 million people all over Afghanistan while now the mobile companies are providing internet facilities for every single subscribers, unfortunately their internet services are very poor and weak. (WorldBank, 2013) 
In a rural country like Afghanistan one third of the economy have been dependent on agriculture fueling the employment and growth of the country. However, the growth in the agriculture is not significant where it was calculated to be $2.5 \%$ in the year 2010 where the target was 5 to $7 \%$ under the program called "Securing Future of Afghanistan". Donors have supported the sector by rehabilitation process of the irrigation system and provided agricultural services. Yet, donors have defined issues in the implementation. According to the US report, six out of eight programs failed in achieving annual targets that were assessed by GoA where the performance decreased in the running programs from 2006 to 2008. According to the donors the project failures are due to the ineffective Ministry of Agriculture, Irrigation and Livestock. On the other hand it can be perceived that the donor's assistance to boost the level of productivity of the agriculture was not sufficient in the field of agriculture and livestock. In addition to that the foreign aid has not been able to improve the Afghanistan competitiveness or even increase the rural income or reduce the level of rural poverty. According to the donors of the program "ADADP", it has supported the development of rural areas in Afghanistan however there is lack of information that could prove the claim when the UNDP (2009) reports states it to be completely ineffective. (ANDS I. R., 2008/09)

The program initiated by US government called Agriculture Vouchers for Increased Production in Afghanistan was started in order to support the agriculture that granted cash for the rural people for work with the hope that the cash would boost the agriculture production. However, the outcome of the program had yet again seemed ineffective and the assessment reports termed it as doubtful that questioned the job creation and subsequent unintended consequences of inflating incomes on a temporary base that fell back when the funding was stopped. The overall result of the donor's effort in boosting the Afghan agriculture is not effective. The main issue is the lack of strategy and aim of the donors in the sector of agriculture. The assessment of DFID (2009) states that there is a requirement for much focus on the investment issues in water, labor, land and credit management. (Hamayoon, 2015) 


\section{Transparency and Accountability}

Some of the Afghanistan donor countries and those NGOs who are working as subcontractors with government of Afghanistan didn't shared their spending details about their projects in the country, it is really difficult to understand their transparency and accountability, also it is not believable their commitments to the developmental projects, might be almost difficult for the aid giving countries to fulfil their promises and commitments to taxpayers to improve their productivity and effectiveness. The government of Afghanistan since 2001 didn't know about the donor countries project contributions because there is little or no information about foreign aid to the country. There are still some donors who are not sharing their aid information about the development projects in the country. In accordance to some researchers in Afghanistan many of the high positions staff refuses to share the project costs while there are other donors whom sharing incomplete data about the projects, and there are less donors who have submitted full information about their projects. (Waldman, 2008)

Under Paris declaration there is some small requirements for donor countries to share their accountability, since the government of Afghanistan on its compact have 77 standards to spend foreign aid in the country although there is parliamentary evaluation and monitoring system as well but the international donor's performance is not much publicized and that are confidential. Unfortunately there no good system of monitoring to review the donors performances, the government of Afghanistan cannot monitor the performance of the foreign NGOs and international organizations, they are responsible for their own countries, the reporting system to the government of Afghanistan is improved but that is not sufficient, the projects transparency and accountability is limited or non-existent. (Waldman, 2008)

The Afghanistan compact which was assigned in 2006, under annex 2 all donor countries are asked to be committed for efficient and effective use of foreign aid. There is many differences in the commitment of efficient and 
effective use of foreign aid, according some reports about $40 \%$ of the foreign is not used in Afghanistan, which most of them flows back to the donor countries due to their profit and high salaries. (Waldman, 2008)

We should not be in doubt that reconstruction process of the country is not possible with the contractors, but the there is an important question which must be asked from the donors and contractors how much they have used the foreign assistance effectively and efficiently? In the year 2006 the World Bank director to Afghanistan has mentioned on a report about $40 \%$ of the foreign assistance is misused and there is real robbing of foreign aid is ongoing, which is a very critical challenge for the foreign assistance to country. (Waldman, 2008)

In some of big contracts in the country, there are more than four layers whom are making contracts for one projects, which is definitely effected on the projects and each of the contractors have their own profits in the contracts, that is why many of the foreign assistance is misused, in some of the cases there is $50 \%$ profit in the contract layers which is a critical issue for the quality of the development projects in Afghanistan. (Waldman, 2008)

There are a lot of examples that foreign is misused in Afghanistan one that examples as Kabul press brings on its report is the reconstruction of maternity hospital in khair khana area of Kabul city, the fund was allocated by Italy to UNFPA who subcontracted the project with UNOPS, the UNOPS subcontracted the project with total a amount of $\$ 2.2$ million again with an Italian company but unfortunately the project is sub contracted again with an afghan construction company, Kabul press reported that half of the budget which is mentioned above spent on the project, the reports mentioned that quality of the project was really poor. (Waldman, 2008)

The provincial example can be the construction of a road in Badakhshan province, this road is located in Faizabad district of Badakhshan province, which was sub contracted whit non-governmental organization by USAID with the total amount of $\$ 500,000$ five hundred thousand dollar, local authorities says that the 
projects is again subcontracted with an Afghan private company with half of the budget allocated for the construction of the road. (Waldman, 2008)

Foreign aid is wasted in Afghanistan due to paying high salaries, living costs, transports costs and accommodation costs and security allowances for the foreign employees and consultants. The foreign consultants were assigned to support technically the projects and they were hired by donor countries. There is some cases in Afghanistan that some foreign consultant were paid $\$ 250,000$ dollar per year while the afghan civil servant were paid less than $\$ 1000$ in a year. (Waldman, 2008)

\section{Provincial Development Plan Goals}

The Provincial Development Plan Goals is the strategic goals for Panjshir province which has developed for three to five years due to the needs and priorities, that has been contributed by the people. The purpose of the PDP is to work out the current development programs with the consultation of each other in order to make sure that the process is effectively ongoing according to the people needs, as well as the PDP presents a number of projects that has been recommended by members of provincial authority and local habitants as priority projects. The PDP is meant to solve the needs, priority projects for people in the next year. (ANDS S. , 2007)

The goals and strategies of PDP according to strategic sectors and Afghanistan National Development Strategy which is infrastructure of planning and decision making for nationwide. The purpose to these actions are to make sure that development activities are going forward to the aims of national development, this is meant to give the most effective response to the specific needs and priorities of each provinces, districts and local nations in process of development. (ANDS S. , 2007) 
Therefore, the PDP provides a clear guidance, which regulates the current sources of the Government, Donors and contributors to make sure that these sources has targeted the most important problems in local habitants and has pointed out to solve. The PDP explains clears goals, needs and priorities of the people in process of development within the province, which has been negotiated by the local habitants and has been agreed on. (ANDS S. , 2007)

The specification of ten top priorities projects in all eight sectors the Afghanistan national development strategy that participants thinks in year 2008 (1387) should start with implementation, all government ministries, pertinent departments at the provincial level, PRTs, national organizations, NGOs, Donors communities that are active in districts should pick the first step and to focus on coordination and development of programs, to be able to bring lots of needed changes that local habitants has recognized them by their own and may bring the most effective changes to people's life. (ANDS S. , 2007)

From the view point of aid efficiency, ownership can be defined as the country's ability to prioritize and make framework to use the aid properly or ownership is defined as a country's skills and abilities to decide its development priorities to be good strategies and formula's for the development process also to mobilize the budget and institutional resources which is required for the implementation of the projects. The Afghan government mission is to be selfsufficient to its development strategies, to eliminate the poverty or to reduce the poverty rate in the country, the poverty reduction paper of Afghanistan is committed to a framework to reduce the poverty in med term and the key steps has already started to worked against the poverty and still it is in progress to complete the process. (Eric Davin , 2008)

The government of Afghanistan has complete and finalized the National Development Strategy (ANDS), the GoA's long term objective is to achieve the Millennium Development goals in the year 2020. The strategy clearly indicated that sustainable growth is the priority for the government of Afghanistan, the strategy was firstly drafted in 2006 to set goals and objectives for the sustainable 
development of the country. The ANDS is actively prepared by the participation of government ministries, donors, civil society and the national and international organizations in the country. (Eric Davin , 2008)

The ANDS clarifies the objectives and goals for the each individual sector in the country, by seeing the situation now in Afghanistan the ANDS aims to identify the opportunities and strong points for getting good results and to achieve the goals of the ANDS, the Afghanistan government remains committed to help all sectors including public and private to achieve their goals. (Eric Davin , 2008)

\section{Aid Effectiveness in Afghanistan}

The Afghan government will remain committed to Paris declaration as the keystone of the Afghanistan National Development Strategy (ANDS). From the begging of the 2001 the country has received billions of dollars foreign assistance to rebuild the country's infrastructure including the security sectors, as of 2013 official assistance to Afghanistan since 2001 makes the amount of $\$ 40$ to $\$ 50$ billion which in the mentioned amount the security sector is excluded and that is not officially reported in OECD DAC aid reporting system. (ANDS G. o., 20082013)

The Afghan government is committed to use the foreign aid properly for the development of the country and to bring peace and prosperity to the people of the country, the government objective is to implement the afghan compact and ANDS strategy successfully and efficiently, in the recent years the government has focused on the emergency needs in the rural communities as well as in urban areas of the country. The government claims that foreign assistance to the country is not sufficient, the government principle is to ensure that donor's funds might be spent in the very effective way alongside with the ANDS priorities. (ANDS G. o., 2008-2013) 
There are other objectives to the afghan ANDS strategy that is ownership, which is indeed very important for the coordination, management and unity in the country to get good result and shared accountability, the government of Afghanistan is agreed with the Paris declaration and its own compact to use the aid effectively and efficiently, to improve the delivery and impact of the foreign aid. The government aid assistance strategy and alongside with the main doctrines of the Paris declaration whereby international colleagues own and apply leadership over their development strategies donors line up. (ANDS G. o., 20082013)

The impact of foreign assistance can be measured with the progress towards the accomplishment of MDG, Afghan Compact and ANDS poverty reduction and growth targets. Many of them has already been achieved in the recent years, but it needs to work hard to achieve more, Afghanistan current situation is dependent on foreign aid, it needs to be help and support more until it is improved economically.

Many of the Afghanistan infrastructure system is destroyed and damaged during the past 30 years of war, since 2001 there is noticeable achievement and improvement in the lives of people because of foreign assistance to country, the people's average income per capita have been increased and doubled from 2001 to 2007 from $\$ 150$ to $\$ 290$, there are millions of child are enrolled in the primary and secondary education while in 2000 and before of that there was no good education improvement, many of the infrastructure has been rebuilt or constructed such as health care center, transportation system and agriculture. Around 5 million afghan immigrant in the foreign countries have returned back to home, also living standards were improved in the rural and urban areas of the country. (ANDS G. o., 2008-2013)

The different category or type of Aid and its desired outcome determines the mechanism of the foreign aid that leads towards the positive or negative economic results. In addition to that, foreign aid has influenced the credit constraints of the government allowing them to develop and invest in the human 
capital and public infrastructure that also assist growing. However, the foreign aid, directly increases or decreases the exchange rates in the country markets, foreign aid also has its impact on the import and export prices and reduces the amount of competition in the industrial sector.

According to the World Bank (2011) the international aid is generating majority of the Afghanistan's GDP from the past ten years. The adequate implementation of foreign aid in Afghanistan can promote security, foster economic development, build governance and support the civil society. The foreign aid has played an effective role in the creating stable conditions for the democratic government that is able to resist the terrorist attacks and insurgent groups especially from creating safe heavens in Afghanistan. The foreign aid of \$3.2 billion granted to Afghanistan in the year 2012 from the USAID has improved the military and the basic Afghan capacity. (ANDS I. R., 2008/09)

According to the foreign aid has successfully achieved the on-budget National Solidarity Program that has effectively strengthened the local governance and their subsequent traditions leading towards the central institutions of Afghanistan. Guggenheim states that foreign aid for the National Solidarity Program works effectively due to the fact that government role is simple yet strong and the implementation is outsourced to the Afghan local communities where the disbursements are streamlined and transparent. According to the evaluation from SIGAR the foreign aid for NSP has been the most successful as the community involvement in development activities has created a sense of ownership in the community. The foreign aid has thus created a community infrastructure that helps in creation of ongoing governance. (ANDS G. o., 20082013)

BPHS is another example of effective foreign aid in Afghanistan that was established in the year 2003. According to the BPHS has improved coordination among the donors, Afghan Government and NGOs which has improved the primary health care sector. In addition to that the foreign aid has been effective in the shape of Performance Based Governors Fund that empowers provincial 
governors through granting budgets to establish relationship between overall management capacity and its constituents. (ANDS G. o., 2008-2013) 


\section{Chapter III}

\section{Research Methods}

\section{Target Group and Sampling}

The purpose of this research is to understand the effectiveness of foreign aid in rural development of Afghanistan a case study in panjshir province of Afghanistan, since the research on rural development of Afghanistan is broader area of study that can include numerous type of analysis, and years of study. Therefore, the researcher chooses panjshir province of Afghanistan to make the dissertation area small and can do survey in the province. This study is to know that how the foreign aid effected in the rural development of Afghanistan specifically in panjshir province of Afghanistan.

Target population for this study is three hundred people (300) whom are living in panjshir province of Afghanistan and some rural organization employees whom are directly involved in the development projects of the province.

\section{Sample Size}

An organized questionnaire designed with the coordination of advisor for this research. The researcher has determined to study almost $80 \%$ percent of the population which makes a total of 236 respondents. Considering a known population of the research, the researcher has chosen a widely and comprehensively used technique of random sampling for 50 percent targeted population. The researcher has distributed the questionnaires randomly to the people of panjshir province and the rural development organization. While the collection of the questionnaires, more than 60 respondents were failed to give back the questionnaires or have not filled the questionnaires at all. And the researcher had left with only 236 filled questionnaires. Before inserting the data 
into the statistical program (SPSS) for analysis purpose, 15 questionnaires failed to match the requirements and were incomplete to pursue further analysis on them, therefore, only 221 questionnaires which were valid for analysis into the SPSS and were proceeded to carry on for further analysis.

\section{Data and Procedure}

The information in this research is extracted from primary and secondary sources of information, the researcher used books, journals, newspapers and research papers for collecting secondary information, and for the primary source of information, the main tool was questionnaires and personal visits with panjshir province people and the rural development organization in the country. The researcher followed the following structures for each of the rural development analysis in this research, hereafter.

Initially, each of the questions related to rural development will be described statistically that will state the frequency percentage response of the respondents.

The primary data of this research is the information collected from 221 people of Panjshir province and the rural development organization employees in the country. This information was generated from a questionnaire with three sections including an angle question for gender and followed by nine specified Likert scale questions about the effectiveness of foreign aid in rural development of panjshir province also the questionnaire includes four open questions to find the peoples mind on the effectiveness of foreign aid in rural development in the province.

The researcher used reliable sources of secondary information such as book, newspapers, journals, and research papers for information gathering. The list of all sources used in this research has been noted. 
This study only provides a guideline on effectiveness of foreign aid in rural development of Afghanistan a case study in panjshir province of Afghanistan. The researcher has used the people's idea of the province and the employees whom are working with the rural development organization in both panjshir province and the capital city Kabul (as a primary data) for the preparation of this report. For secondary data, I have reviewed the related studies which have been already researched same to this thesis topic and those books, journals, newspapers, websites and interviews.

A minority number of the respondents were approached via a personal network and sources of the researcher which may incorporate some chances of error and lessen the reliably of accuracy in filling the questionnaires. 


\section{Chapter IV}

\section{Data Analysis and findings}

The following data analysis is collected by the help of questionnaire in Afghanistan which is showing the effectiveness of foreign aid in rural development of panjshir province in Afghanistan. This thesis is analyzed by SPSS software program which is a valid analyzing method for every social research in the world and I used for this thesis too, the separate tables in bellow shows the statics for each part of the questionnaire and the questions, also each part is interpreted individually based on the findings by the help of the questionnaire.

Table 3: Sex table

\begin{tabular}{cccccc}
\hline & & Frequency & Percent & $\begin{array}{c}\text { Valid } \\
\text { Percent }\end{array}$ & Cumulative Percent \\
\hline \multirow{2}{*}{ Valid } & Male & 170 & 76.9 & 76.9 & 76.9 \\
& Female & 51 & 23.1 & 23.1 & 100.0 \\
\hline & Total & 221 & 100.0 & 100.0 & \\
\hline
\end{tabular}

The above frequency table number 3 shows the result of how many people have participated in the survey for this thesis writing from target population of the survey, from the total of 300 target people almost $80 \%$ people participated and returned the questionnaire and makes the number of 221 person which is valid for the data analyzing. 
Table 4: Does Afghanistan need more Foreign Aid for its Rural Development?

\begin{tabular}{cccccc}
\hline & Frequency & Percent & $\begin{array}{c}\text { Valid } \\
\text { Percent }\end{array}$ & $\begin{array}{c}\text { Cumulative } \\
\text { Percent }\end{array}$ \\
\hline \multirow{2}{*}{ Valid } & Yes & 210 & 95.0 & 95.0 & 95.0 \\
\hline & No & 11 & 5.0 & 5.0 & 100.0 \\
\hline
\end{tabular}

The table above shows the result for the question number one which was asked about the need of foreign aid to Afghanistan by the donor countries, the respondent for this question is really amazing because the Afghanistan people still thinking that their country need more foreign aid for the development projects of the country, in the past 15 years the international community have helped Afghanistan by millions of dollars, the result of the question shows that $95 \%$ people are asking foreign aid for the developmental projects of rural development, as a researcher I can say that our people in Afghanistan they are not asking budget from the government because they know that government cannot support the development projects without the help of the foreign friends, so they are calling for the international community to help them regarding the rural development projects in the country. 
Table 5: Infrastructure is the priority for sustainable rural development in Panjshir province.

\begin{tabular}{cccccc}
\hline & Frequency & Percent & $\begin{array}{c}\text { Valid } \\
\text { Percent }\end{array}$ & $\begin{array}{c}\text { Cumulative } \\
\text { Percent }\end{array}$ \\
\hline \multirow{4}{*}{ Valid } & Strongly & 95 & 43.0 & 43.0 & 43.0 \\
& Agree & & & & \\
& Agree & 94 & 42.5 & 42.5 & 85.5 \\
& Uncertain & 19 & 8.6 & 8.6 & 94.1 \\
& Disagree & 6 & 2.7 & 2.7 & 96.8 \\
& Strongly & 7 & 3.2 & 3.2 & 100.0 \\
& Disagree & & & & \\
\hline
\end{tabular}

The above table shows that infrastructure is the system of serving people by making them life facilities like industries, universities, schools, health care centers and many more in a country, province, city, town or an area. The infrastructure should change the people's life and must improve the people's life facilities. The data in the table 5 shows the result for the question number two of the questionnaire which have been asked about infrastructure's priority for sustainable rural development in panjshir province, as we all know that making the infrastructure should be the first thing in the development of country or a community in this research survey the people of panjshir province responded that they want to build their infrastructure in the first steps of the development, the statistics in the table 5 shows that $43 \%$ people are strongly and $42.5 \%$ people are agree to build their infrastructure as a first development projects.

As we look back to the table 5 less the $6 \%$ people of panjshir province are not agree for building the infrastructure in the province, majority of the people thinks that they want to build the infrastructure for the development of their province, if we look back to the developmental projects in the developed countries they have worked for the sustainable development in their countries, 
like they have built big manufacturing companies, roads, universities and so on based on the need of the people, the panjshir people also want these kind of development projects.

Table 5: Foreign aid has been used properly in rural development of Afghanistan so far.

\begin{tabular}{cccccc}
\hline & Frequency & Percent & $\begin{array}{c}\text { Valid } \\
\text { Percent }\end{array}$ & $\begin{array}{c}\text { Cumulative } \\
\text { Percent }\end{array}$ \\
\hline $\begin{array}{c}\text { Strongly } \\
\text { Agree }\end{array}$ & 28 & 12.7 & 12.7 & 12.7 \\
& Agree & 86 & 38.9 & 38.9 & 51.6 \\
Valid & Uncertain & 59 & 26.7 & 26.7 & 78.3 \\
& Disagree & 30 & 13.6 & 13.6 & 91.9 \\
& Strongly & 18 & 8.1 & 8.1 & 100.0 \\
\hline Disagree & & & & \\
\hline
\end{tabular}

The above data in table number 6 indicates that the foreign aid has been used properly in rural development of Afghanistan so far. The repliers to this question are in different mode of replying to this question as we see the table, it shows that many people thinks that foreign aid is used properly in the rural development projects of their province and the percentage of their response makes it valid because it is almost $52 \%$, and there are other people whom they are thinking that foreign aid is not used properly based on their need and rural development projects of their province, also some people really don't know about the rural projects in their province and did not have any idea about it and those are $26.7 \%$ from all of the respondents. 
For the use of aid in a proper way in the rural development of the country we need strong leadership and project management that we can use aid based on peoples need, the government should take care of its developmental projects and must look back to the maintenance of rural development projects and all developmental projects, if the projects will not maintenance I can surly say that, life of the projects will decrease to its lowest rate and finally we might not have development in the country.

Table 6: Foreign aid has been used in Panjshir province based on understanding of people's need.

\begin{tabular}{cccccc}
\hline & Frequency & Percent & $\begin{array}{r}\text { Valid } \\
\text { Percent }\end{array}$ & $\begin{array}{c}\text { Cumulative } \\
\text { Percent }\end{array}$ \\
\hline \multirow{4}{*}{ Valid } & $\begin{array}{c}\text { Strongly } \\
\text { Agree }\end{array}$ & 48 & 21.7 & 21.7 & 21.7 \\
& Agree & 75 & 33.9 & 33.9 & 55.7 \\
& Uncertain & 53 & 24.0 & 24.0 & 79.6 \\
& Disagree & 26 & 11.8 & 11.8 & 91.4 \\
& Strongly & 19 & 8.6 & 8.6 & 100.0 \\
& Disagree & & & & \\
\hline & Total & 221 & 100.0 & 100.0 & \\
\hline
\end{tabular}

The data in the table chart number 7 has shown the use of foreign aid in rural development of panjshir province based on the understanding of peoples need, from the total valid percentage of the statement in the table number 7 , $21.7 \%$ people are strongly agree for the use of foreign aid based on the peoples need in their province and the remaining percentage $33.9 \%$ are agree to statement asked in the questionnaire, the uncertain percentage for the statement above is $24 \%$ which people says that they don't know whether if the aid is used based on 
the peoples need or not, the mentioned percentage of the uncertain choice in the table 4.12 indicates that people don't have any idea for statement which have been asked in the questionnaire.

Aid from the donor countries must be used based on the peoples need, the aid to recipient countries must help poor people and reduce the rate of poverty, and aid comes with the price of its own to the developing countries and must respond the need of people otherwise if the aid from donor to recipient people does not respond their need I can say that is priceless and I cannot call it aid and helping people, in this regard I will say that aid from donor to the developmental nations must target the peoples need, targeting the peoples need itself is fight against poverty.

Table 7: Foreign Aid helped the process of rural development in Panjshir province.

\begin{tabular}{rccccc}
\hline & Frequency & Percent & $\begin{array}{c}\text { Valid } \\
\text { Percent }\end{array}$ & $\begin{array}{c}\text { Cumulative } \\
\text { Percent }\end{array}$ \\
\hline $\begin{array}{c}\text { Strongly } \\
\text { Agree } \\
\text { Agree }\end{array}$ & 52 & 23.5 & 23.5 & 23.5 \\
& 115 & 52.0 & 52.0 & 75.6 \\
Valid & Uncertain & 34 & 15.4 & 15.4 & 91.0 \\
& Disagree & 14 & 6.3 & 6.3 & 97.3 \\
& Strongly & 6 & 2.7 & 2.7 & 100.0 \\
Disagree & Total & 221 & 100.0 & 100.0 & \\
\hline
\end{tabular}

The data in the table number 8 shows the result for the statement of foreign aid helped the process of rural development in panjshir province, the 
mentioned chart data is collected by the help of questionnaire in panjshir province of Afghanistan in which most people responded to the statement above as a percentage of $23.5 \%$ strongly agree and $52 \%$ agree to the statement in the questionnaire, from these two choices of the statement I can get the result that people in panjshir province believes that foreign aid helped the process rural development in their province, for the remaining percentages of uncertain, disagree and strongly disagree you can see the table number 8 .

Foreign aid must help the process of development projects in a country or a community which must help the poorer people of that area, foreign aid can help to speed up the process of developing projects, foreign aid can promote the projects which is going to be implemented in the developing nations and can create new economics and human developments. If the foreign aid will not help the process of development projects, that is misused and the donors must find the problem for the project implementation also they can crosscut the aid to the projects.

Table 8: Rural development should be the first priority of government for utilizing Foreign Aid.

\begin{tabular}{cccccc}
\hline & & Frequency & Percent & $\begin{array}{c}\text { Valid } \\
\text { Percent }\end{array}$ & $\begin{array}{c}\text { Cumulative } \\
\text { Percent }\end{array}$ \\
\hline \multirow{3}{*}{ Vtrongly Agree } & 75 & 33.9 & 33.9 & 33.9 \\
& Agree & 62 & 28.1 & 28.1 & 62.0 \\
& Uncertain & 47 & 21.3 & 21.3 & 83.3 \\
& Disagree & 29 & 13.1 & 13.1 & 96.4 \\
& Strongly & 8 & 3.6 & 3.6 & 100.0 \\
& Disagree & & & & \\
\hline Total & 221 & 100.0 & 100.0 & \\
\hline
\end{tabular}


The data in the above table number 9 shows the result for the statement which is mentioned in the questionnaire that rural development projects should be the first priority for the government of Afghanistan to utilize it in the rural projects, the statement table number 9 indicates that rural development should be the first priority for the government to spend the foreign aid in rural development, $33.9 \%$ people are strongly agree and asking the government to spend the aid from donors in the rural development projects because they believes that by connecting the rural areas, they can easily connects to each other and access to the public centers like hospitals, universities, schools and etc. the percentage of choice agree to the statement is $28.1 \%$ and this percentage makes the people idea very true and they want the government to spend more on the rural development projects. For the remaining percentages of the statement you can check the table data.

Rural development in the country is really needed, many people of Afghanistan is living in the rural areas and they really don't have access to the first needs of the life and that is their right to access for basic and fundamental necessities in their life, as human I believe that everyone in the world should be treated equally.

Table 9: Aid is required to address the short-term challenges and sustainable poverty reduction in the Panjshir province.

\begin{tabular}{cccccc}
\hline & Frequency & Percent & $\begin{array}{c}\text { Valid } \\
\text { Percent }\end{array}$ & $\begin{array}{c}\text { Cumulative } \\
\text { Percent }\end{array}$ \\
\hline \multirow{4}{*}{ Valid } & Strongly & 88 & 39.8 & 39.8 & 39.8 \\
& Agree & & & & \\
& Agree & 98 & 44.3 & 44.3 & 84.2 \\
& Uncertain & 20 & 9.0 & 9.0 & 93.2 \\
& Disagree & 11 & 5.0 & 5.0 & 98.2 \\
& Strongly & 4 & 1.8 & 1.8 & 100.0 \\
& Disagree & & & & \\
\hline
\end{tabular}


The data in the table 10 specifies the result for the statement of; aid is required to address the short-term challenges and sustainable poverty reduction in the panjshir province of Afghanistan, the people's reaction to the statement is different, according to the data in the table 10 from total $100 \%$ many of them are strongly agree and agree, which makes the percentage for strongly agree $39.8 \%$ and for agree it is $44.3 \%$ the people thinks that aid can change the short-term challenges and they believes to address the challenges that is really harmful to their life now.

In long term as the result shows in the table 10 many people want to eradicate the poverty in their province and all over the country, foreign aid can help them to eliminate the poverty in their area, as many of us know that poverty is the human enemy and killing their life every day and it is increasing day by day, the international community turned their attention to reduce the world hunger problem, in this regard many conferences have been held successfully and made commitment to eradicate the poverty in the world. This kind of world attention to poverty reduction, the situation would be changed and is a step forward in reducing poverty all over the world, people in panjshir province thinks that foreign aid is a stage of reducing poverty in their province.

Table 10: Aid is centralized and top-heavily focusing on Kabul and other urban cities.

\begin{tabular}{cccccc}
\hline & Frequency & Percent & $\begin{array}{c}\text { Valid } \\
\text { Percent }\end{array}$ & $\begin{array}{c}\text { Cumulative } \\
\text { Percent }\end{array}$ \\
\hline \multirow{4}{*}{ Valid } & Strongly Agree & 65 & 29.4 & 29.4 & 29.4 \\
& Agree & 50 & 22.6 & 22.6 & 52.0 \\
& Uncertain & 58 & 26.2 & 26.2 & 78.3 \\
& Disagree & 38 & 17.2 & 17.2 & 95.5 \\
& Strongly & 10 & 4.5 & 4.5 & 100.0 \\
& Disagree & & & & \\
\hline
\end{tabular}


The above table data shows the result for the statement which was asked in the questionnaire for the current thesis writing on the effectiveness of foreign aid in rural development of Afghanistan a case study in panjshir province of Afghanistan, the statement is indicating on the centralization of foreign aid and its top focusing on Kabul province and other urban cities of Afghanistan, the respondent to this statement have extremely strongly agree that foreign aid is used in big cities of Afghanistan and the percentage for the first choice is $29.4 \%$ for the choice agree the percentage is $22.6 \%$ for the remaining choices please check the table 11 and the data of it.

People in panjshir province believes that urban and capital cities have been more focused regarding the uses of foreign aid for developing rural areas. Panjshir province of Afghanistan is one of the 34 provinces in the country and it is less developed in accordance to other provinces of the country, rural development projects are less implemented in the province, the residents of panjshir province want more projects for its rural development and making facilities and access to the central provinces and many other facilities in the their province. Growth and development is important for every single human in the world by stating this sentence that is our right to development and accelerate our reduction income poverty rate in the region and across the country.

Table 11: Do you believe that foreign aid is helpful for the developmental projects in the country?

\begin{tabular}{cccccc}
\hline & Frequency & Percent & $\begin{array}{c}\text { Valid } \\
\text { Percent }\end{array}$ & $\begin{array}{c}\text { Cumulative } \\
\text { Percent }\end{array}$ \\
\hline \multirow{2}{*}{ Valid } & Yes & 148 & 67.0 & 67.0 & 67.0 \\
& No & 17 & 7.7 & 7.7 & 74.7 \\
& Maybe & 56 & 25.3 & 25.3 & 100.0 \\
\hline
\end{tabular}


The data in the above table number 12 shows the result for the last closed question of the questionnaire which is asked that: do you believe that foreign aid is helpful for the developmental projects in the country, the result is surprisingly 67\% strongly agree, people in Afghanistan still waiting for the foreign aid, and wants the international community to help them for the development projects in the country. The other part of the table and the data indicates that maybe we need foreign aid which the percentage is not much high and it is $25.3 \%$, the question clearly explains the idea of the people of Afghanistan whom are surveyed for this thesis writing that they really need foreign aid for the development projects to change their life and have better life in the future.

The international community and rich countries in the world could help poor nations for their better life. The donor countries can help their recipient nations in the world in infrastructure and really needed ground works, by this they can have sustainable development and way to eradicate the poverty in developing countries.

The people of Afghanistan is one of the nations in the world which they are poor and need help in every sections of developing especially the infrastructure should be the priority, afghan people have improved and understands the main sources of growth and can help the process of poverty reduction while there is still more lessons to learn. 


\section{Main Problem of Rural Development in Panjshir}

The following argument is regarding the main problem of rural development in panjshir province, people have mentioned variety of problems. The first challenge in the country is security problems, majority of the people have been effected by war in the country, during the last decades. Security challenges are the main problems for the development projects in the country. Specifically panjshir province is not exceptional from this problem in Afghanistan, people in panjshir province believes that development cannot occur if there is no secure places as first steps of the development, this is not only the problem of security which is effecting and stopping the developmental projects in the province also can destroy the infrastructure and insecurity will cause development to go backward, insecurity will bring the poverty to the society, the security challenges will make problems for every single development projects in the province and to the country.

Social problems are the effect of bad things within a society, that usually happening in the communities and making difficulties in the societies and they are challenge for the rural development in panjshir province too, Afghanistan is one of those countries in the world which is in transition to a new period of life and cannot be secure in terms of social problems as will, the people in villages, they are mentioning some parts of their social problem as an example, like they have mentioned the personal problems as a public issue which is a big challenge for the province development, powerful people and local authority whom are from a special place, they want all the developmental projects for their own benefits and that is not helping villagers in the province so they are mentioning this problem as a social challenges or unemployment is a problem which is effecting thousands of people in the province and they are emphasizing to reduce the rate of employment in panjshir province, people are addressing government to help them for this problem and make them facilities. 
Community participation can be defined as an active involvement of people in communities' public works to solve their own societies' problem, unfortunately this is not happing in panjshir province and there is lack of community participation in the province, community participation doesn't mean that they are not working physically in the area but the people are criticizing on not sharing their ideas and not taking responsibilities for the development projects. We cannot force people to work in their societies unless if they don't want to participate, people's role in succeeding a rural development project is very important, this is people who can fail or succeed the projects in their own villages, so people's participation is really essential to do good job in the communities.

People in panjshir province cannot select the priority of their need, also an overall idea about the people in Afghanistan, they are not knowledgeable to prioritize their need based on their own understandings, and tragically panjshir province is one of them, people that they are failed in terms of their really needing projects for the province rehabilitation and reconstruction is because of their lack of the knowledge and awareness from the community. Existing of irresponsible war lord in the area is another problem which have affected the illiteracy of communities and they are lacking this big opportunity.

The problem of land donation in Afghanistan is a big challenge for the infrastructure projects and this problem remains one of the main challenges in panjshir province as well, nearly the entire province (91.2\%) is mountainous or semi mountainous terrain while only about $4.4 \%$ of the area is made up of flat land. People in panjshir province doesn't want to donate their private land for the public services due to some certain reasons, agricultural land is the only income source in the province that is why people are not going to donate their land for the public services, people knows that land donation will help the process of rural development projects but due to lack of job opportunities and lack of other sources of income are the reason they don't want to donate land for the development projects, as I mentioned above that panjshir province is mountainous 
valley that's why the mountainous geography itself is a challenge for rural development projects because the implementation of rural development projects in the mountain areas needs a lot of budget and the government is not able to implement these projects.

The infrastructure projects are not constructed nor reconstructed claimed by panjshir province people by the help questionnaire which is designed for this thesis writing, the infrastructure projects are those projects which are the fundamental and physical system of a community or the entire country; like transportation, roads, tunnels, agriculture, healthcare centers, schools and universities, these are the basic needs of the panjshir province, they claimed that the mentioned projects are very important in sustainable development of the province and for the whole country, if the infrastructures are constructed we can have good economic system and the poverty can be eradicated by having the system for sustainable development.

Lack of working on agricultural projects is also a problem in the fundamental projects of panjshir province of Afghanistan, the country's basic economic is agriculture and is really needed to work for the development of agriculture in the country and pacifically in panjshir province of Afghanistan, the Afghanistan economy is based on the agriculture while only $12 \%$ of its land is arable and about $6 \%$ is currently cultivating. According to the responded in 2007 the country's total exports of the fresh fruit is around \$113 USD million in the year, they also mentioned if the process is kept like this our country's export in terms of fresh fruits and other dry fruits will be grown dramatically in 10 years and the amount will be $\$ 800$ USD million per year. According to their claim if we invest in the agriculture we can have sustainable development for the people in the country and panjshir province of Afghanistan. Panjshir province is known for the mulberry and walnuts. There is also a problem in the agriculture system of panjshir province which is lack of experts in agriculture and development projects of agriculture, the people really need these experts for the developmental projects, if not they will not be able to have high level of economic and good agriculture. 
Management of a projects needs a lot of skills and experience, lack of strong management from in the development projects of panjshir province is a big problem, this challenge have affected the projects to be not sustainable and effective, successful project managers are in a high level of skills that can organize the projects at faster and makes the projects successful but unfortunately these managers are a dream in the rural development projects in panjshir province of Afghanistan, claimed by people in the province. A project managers should have the knowledge, interpersonal and leadership skills, time management and good communication skill about the projects by having these skills they can complete the rural development projects successful. As people said in the interviews there is no good master plan for the infrastructure projects in panjshir, they are asking the local authorities to make a master good master plan for the development of the province,

The Influence of powerful local authority in rural development projects is a serious problem in the implementation of rural development projects, they are asking the officials to make the projects in their own benefit otherwise it would almost impossible to go forward and make the projects successful, the local authorities are those people whom are not officially nominated by government, but they are playing a role of village leader in the community, construction of the rural development projects in each province is going to be implemented by the help of these authorities but unfortunately as people said in the survey questionnaire they are too much corrupt and wants every single projects on their own benefit, if not it is not possible to complete the project and help the poor villagers, nobody in the village can say anything to them because they have the power on their own hand, whatever they want is possible.

Unfortunately this is another problem of rural development projects in Afghanistan, especially in panjshir province, because rural development projects in the country has an influence of the local authority, officials of the projects, and some other powerful people they are making the projects quality in low level because of their corruption, the companies who are contracting the rural 
development projects they are forcing to give bribe for the local authorities, powerful people in the community and also the officials otherwise they are not able to make contract with them, here the companies due to corruption they are doing their job in low quality that's why unsustainability happens in the projects, also nobody will monitor the projects because of their corruption, people of panjshir province is really unhappy because of this problem and wants the government to monitor from its projects in the country as well as in panjshir province.

Team work is known as key factor in the successes of a project or team work is joint work with a group of people in order to reach a goal, team work is necessary and important issue in the project implementation to work together for achieving the goals, I believe that team work is the first steps of the successes of a project, team work can support the networks among the colleagues also will bring happiness and good performance in the project implementation, team work brings unity for the people and making responsibility for everyone equally, team work can remove the obstacles and brings smoother movement towards the target, unfortunately people have mentioned about lack of team work in panjshir province rural development projects there is no team work, every individual is asking their own idea and forcing it to others, which is really bad for taking best results from the ongoing and upcoming projects of development in the country.

Unfortunately corruption is one of the main and tragic problem in Afghanistan, corruption can be defined as a group of performance for private or group benefits, corruption in Afghanistan is a big problem that has affected all sectors around the country, not even a single small project is exceptional if you want to find this tragic problem on its documents you can do it easily, rural development projects are not secure from corruption problem, panjshir people have mentioned some very tragic stories about this problem, when the ministry of rural development wanted to construct a road in the province, local authorities were asking to give them the contract to their own companies if not they were asking their share from the ministry or the contractor to give them bribe 
otherwise they were able to implement the projects even sometimes happened to the contractor to lost their machineries in the area of the projects, this is a very crucial problem in the country which is effected the entire administration in the country. Due to corruption in the country some of the projects have been left uncompleted which this kind of projects have created a lot of challenges in the province and people wants the government to complete these kind of problematic rural development projects.

Need assessment is the process of planning a project or to address the needs of a plan in the project management, finding the needs of the projects and its gaps in the area is, an important step for the project planning, unfortunately there is no need assessment in panjshir province rural development projects, this is what I have found it in the questionnaire for the current thesis writing which have been stated by the people in panjshir province of Afghanistan, the projects are designed based on the wish of the powerful people and the local authorities, regardless of poor people in the area, nobody is going to take care of the their villages and communities, but they really need these projects to be constructed in their village. The influence of powerful people have affected the rural development projects need assessment process, these kind of influence could be found in each and every province of Afghanistan not only in panjshir, an overall idea is that if you have social and political power you can bring a lot of development projects to your province for the reconstruction and rehabilitation of the province otherwise it would be a dream for your province to wait for the development projects based on the peoples need.

As everybody knows that the projects should be monitored timely to ensure the quality of work and its time management to improve the performance and to achieve the goals for the projects, the result for the question of rural development main problems shows that, there is no good monitoring and evaluation system to check the performance of the companies and people who have worked on the projects in the province, people in panjshir province are criticizing the government for their poor performance on the project monitoring 
and evaluation, again the influence of powerful people and corruption in the monitoring system of development projects, is a critical issue which the government should take care of it and do not let them to interference in the projects.

\section{Impact of Foreign Aid in Rural Development of Panjshir}

The foreign aid have affected the peoples life in the last 15 years, like they have mentioned about the poverty reduction from their life, poverty reduction is an affection of foreign aid, the poverty in the country was a major problem and still it is existing, Afghanistan is one of the poorest country in the world, by the help of international communities the country's economic had some growth and some of the rural development projects has been completed because of the foreign aid, in this period of time the people's life have been changed a lot since the construction of rural development projects started in the province, these construction projects brings them facilities to their life, like they have find asphalt roads in their villages, by the help of these projects panjshir province have connected to other cities of the country and to the districts of the province. Will not forget to say that there was some job opportunities because of rural development projects, the chance of finding a job brings them prosperity in to their life and had better life than before.

Due to security problems the investment of foreign aid in some part of the country is not properly organized but overall the effect of foreign aid is sensitive in the country's rehabilitation and reconstruction of new rural development projects, especially the panjshir province is one the sample of rehabilitation in the infrastructure projects, in the past 15 years panjshir province didn't have asphalt roads but now this province is connected to its districts and to other provinces of the country, foreign aid was helpful in the rehabilitation of the country because Afghanistan is one of the poorest country in the world that is why it needs a lot to help them, for the rehabilitation of infrastructure projects such as roads, public health centers, education centers around the country and many other projects, the 
infrastructure is one of the basic and fundamental need of Afghanistan for its economic growth and to rescue the brittle economy of Afghanistan.

People are connected to the basic services centers in the province, by the help of the questionnaire I have found that people in panjshir province is happy for the rural development projects, since in the past they were not able to travel by car to other parts of the province but now they are able to travel by very modern cars to the very far villages in the province, they are able to access the health care centers very easy and take care of the emergency health issues on time and rescue a life. Access to all these facilities is because of the international help which is foreign aid, if you travel to panjshir province you will find the effect of foreign aid in front of your eyes, but people are asking for more aid to their province and want the government to work on the peoples need based projects and the infrastructure projects.

The foreign aid effected the rural rehabilitation and the village's modernization process, the aim of the aid is to reduce the poverty and help the people all over the world. The objective of the international assistance is to the poorer communities is to support them in equal and sustainable economic growth, the rural rehabilitation in panjshir province of Afghanistan is one of the greatest job ever which have been done during the past 15 years. In the last decade panjshir province was one of the poorest province in the country but now in comparison to the last one decade this province is one of the richest province because of rural rehabilitation and construction of the infrastructure and still needed to work more for this province.

Campaign for rural development projects is one of the most successful process, which the people in Afghanistan panjshir province thinks that, it was the campaign role in which people have received information about the rural development projects in panjshir province, the village in panjshir province believes that; giving the correct and appropriate information to the people in order to create effective communication and change their behavior can be very effective in rural development of the province, in today's world the poorest country in 
order to achieve the goals for the rural development projects, they have to campaign for the projects and give the correct information to people for the success of the their projects, providing the correct information to people can help the process as an equal and sustainable rural development. Undoubtedly, mass media and their audience coverage in any society more than any other campaigns can change the public opinion with new innovations and concepts of rural development for the equal and sustainable development across the country, also panjshir province is not the exceptional from this campaign and it is affected.

Although Afghanistan is among those countries that have enough water resources fortunately panjshir province is one of that water resources in the country but in the past few years, non-use of these water resources have been used properly in the country, people didn't have access to clean drinking water while access to clean drinking water is the right of every human in the world, before 15 years ago there was lack of clean drinking water in all over Afghanistan when the international communities turned its attention to Afghanistan, peoples have suggested to government and international NGOs to help them in digging wells for the people because they wanted to access for clean drinking water in their province, people in panjshir province claimed that before digging wells in the province while we were using the water from the sea, our health was affected by different kind of sickness, now we are very lucky that we have access to clean drinking water by the help of international community and the government development projects, now we have good health and there is almost no problem in this regard because people have access to drinking water and many facilities for finding clean drinking water.

During the past three decades of war, Afghanistan's education system is almost completely destroyed, during Taliban's regime in Afghanistan girls were completely pushed up to stop going to school and universities and there was no progress in the education system of the country, I am one of those students who have studied the primary school during the Taliban regime, the educations system was completely religious and their top focus was on the Islamic subjects, there 
was no any other to choose and study, fortunately when the regime was changed in early 2001 the government has focused on the education system, to bring new and modern facilities in the education system, since the new government is a democratic system, you can study whatever you want, the educations sector is improved since 2001 and it is growing to achieve the top priority of educations standards.

People in panjshir province says that when new government have come to power, they were really focusing on education, now by the help of international communities we have built our schools and universities, it is the effect of foreign aid that we have new schools and universities with internationals standards.

Since education plays an important role in everyone's life and it is the basic issue for the development process, education can help you to improve your life standards and will enable people to change their life standards as it is required in new world, the education will help you to understand the people who are living around you and it will be an improvement of education to help others, the education can help the humans to improve their social activities and economical activities and it will benefit to individual and communities. Education will improve the creativity and productivity of your life and raises the entrepreneurship plus technological improvements.

Since 2001 when the international community turned their attention to Afghanistan, advancement of education sector was one of their objective to bring improvement because they know that education improvement can play an important role in the development of the country especially in the rural areas of Afghanistan, for new government of Afghanistan to bring change in the education system was a hope, that is why the government requested to the international communities to help them in this sector and together they have enhanced education system in the country. With assistance of international communities the country's education system has improved a lot and brought many facilities for the children and young students, when the national strategy adopted in 2006 the government has clearly mentioned in the strategy that supporting and education 
basement is their top priority because sustainable development will never be achieved without changing the mindset of the people.

Afghanistan is affected during the years of invasion and civil war, the invasion of aliens and a strong addition to the destruction of physical infrastructure, the war caused enormous waste of human resources too, the war in the country have interrupted and undermined the effectiveness and efficiency as a considerable reconstruction and development work in the country and the process has been stopped for many years, the impact of these wars during the past three decades in the development of infrastructure in the country and as well as top government sources is clearly evident. The roads reconstruction in country have been started after Afghanistan is turned in to the center of the international community attention specially united states of America.

Roads are one of the country's biggest achievement in the past 15 years, building roads in the country is one of the priority for the Islamic Republic of Afghanistan, in past one decade, government have built many kilometers of roads, the government aims to construct roads in the country to make facilities and enable people to such a transport system that can connect people inside and outside their communities, as well as enable people to access to the regions, people in panjshir province have said that before the year 2000 there was no asphalt roads in the province but now we have kilometers of asphalt roads, we are connected to the center of the province and other districts of the province, roads have brings us many facilities like in the past we were unable to go from one district to another district comfort and easy but now fortunately we can easily travel to other districts in the province and outside of the province to connect with the big cities like capital Kabul. Because of good roads in the province we are able to access the health and education centers very relaxed, we are very happy that the international community have helped the government of Afghanistan for building its infrastructure and still we need a lot to work for the infrastructure and development projects. 
The foreign aid in panjshir province of Afghanistan has effected on the enhancing of community economic development, The last 15 years for Afghanistan was a hope of better and modern life, in these past two decades Afghanistan has past many political and social conflict and destruction, the country has started the process of reconstruction and rehabilitation and established a democratic government and was pursued to the urgent needs of the rehabilitation and development. The afghan government is committed for the sustainable and equal development in the country. All these commitment can bring prosperity and success to country's economic development and having better life for all residents of the country. By the help of questionnaire I found that many people in panjshir province thinks that without the help of international community we cannot achieve our economic growth that is help of them that we are now in this stage.

The foreign aid in Afghanistan have helped the process of job opportunity to the people, like many international NGOs are working with families to improve their skills and supporting them financially for a better life conditions, they are helping them to bring facilities to improve their occupational skills in order to achieve their life goals. Aid can help poor people to mobilize their resources and generate income sources for the better life. Unemployment in Afghanistan was a big challenge for the people and still this problems exist in the country, panjshir province is not the exception from this challenge, people hopes that this problem will be removed from their community as soon as possible, because the problem of unemployment creates many other challenges like security, limitation of access to education and etc.

Some people think that foreign aid does not affected due to corruption, corruption refers to an action that resulting from the application of power and government agencies or government-affiliated financial interests of individual or groups, the corruption will occur in taking and giving bribes, giving positions to relatives or relative impressment, this is all the corruption cases in the country, we 
have many other faces of corruption also which exists in the country I will satisfy by mentioning some of them above.

Corruption impacts on the communities daily works and the ongoing projects, the corrupt officials in the communities thinks only for their private benefits rather than the benefits of national and people of the community, the cost of corruption in the country is really high us I can't imagen it, corruption in the rural development projects effected the quality of projects to be very low, definitely it effects the sustainability of the projects too, due to corruption we have low quality of completed project which is already destroyed and there is no more that projects.

Corruption is one of the big challenges in Afghanistan which have affected the foreign aid to the country's rehabilitation, billions of dollars donated to Afghanistan but unfortunately due to corrupt leaders of the government they couldn't manage this billions of dollars in a proper way which can grantee the country's sustainability and development, corruption is the main obstacle for the foreign aid in Afghanistan, undoubtedly corruption affected the people's trust on the government and all the government system in the country.

\section{Effect of Rural Development projects in Panjshir}

The Discussion below is stating the people's idea as a resident of the province to share their experience regarding the rural development changes which is effected by the rural development projects in panjshir province.

Connection of villages to the center of districts and connection of districts to the province and also access of villagers to the markets, health care centers, schools are the effectiveness of foreign aid in our province if you look back 10 years ago there was lack of these services by the help of international communities we are now able to have these facilities in our province, now residents of panjshir province can easily carry out their products to the markets because of access to good asphalt roads, people in panjshir province have said that 
before the year 2000 there was no asphalt roads in the province but now we have kilometers of asphalt roads, we are connected to the center of the province and other districts of the province, roads have brought us many facilities like in the past we were unable to go from one district to another district comfort and easy but now fortunately we can easily travel to other districts in the province and outside of the province to connect with the big cities like capital Kabul.

Access to markets, education centers, healthcare centers and public services centers are the benefits that we have in our province, in comparison to other provinces panjshir have developed a lot in the facilities mentioned above, people's basic needs are available like they have, education centers, asphalt roads, good hospitals, clean drinking water and etc. but still need to work for the development of panjshir province.

Energy in all Afghanistan is providing from hydropower which is not enough to the country and need more energy, Afghanistan is one of those countries that have a lot of water, but unluckily the ministry of water and power is not able to use water and provide the energy from it, if they can make the electric dams in the country we will only not be self-sufficient but we can export the our energy to other countries too, by this we can help our economy to self-sufficient and sustainable. Unfortunately now are importing energy to Afghanistan from other countries to complete the need of energy for the country.

Micro hydropower stations are those kind of stations that provides energy from $5 \mathrm{kw}$ to $100 \mathrm{kw}$ from the flow of water, fortunately panjshir province is one of those places in Afghanistan that have abundant water therefor in recent decade panjshir province build these micro hydropower stations to provide their energy from the mentioned hydro power stations. This is one of the big changes in comparison to other provinces that panjshir is different from them. Recently in one of the districts in panjshir province by the name of Rokha, small hydropower station have been inaugurated, the micro hydropower station in that district is providing $30 \mathrm{~kW}$ energy and 500 families are affected by building this micro 
hydropower station, this is all because of the international community aid to Afghanistan.

Women in Afghanistan really need to help them because the status of women in Afghanistan are in deep concern since they were not able to have their basic rights under the Taliban regime, they were completely deprived from school and other activities in the public services and private sectors, today they are able to go to school, universities and to work in public and private sectors, there are several NGOs whom are working for the women empowerment in the country through the government collaboration and local partners.

Since there are several problems in the country for women which are challenging women in Afghanistan especially in panjshir, the traditions are one of that biggest challenges in the country that women are not much active in each and every parts of development, government of Afghanistan adopted several strategies to protect the women rights in the country, now women have equal rights with men in Afghanistan there is no different in giving the opportunities to the women rather their ability, now women are a power in Afghanistan, for the access to economic activities of women we need to empower the strategies which have been adopted in the past years since 2000 .

One of the biggest opportunities which have been created for women in panjshir is to develop their skills and abilities for better life expectancy, there are some NGOs whom are providing tailoring machines for them to make cloths and to sell it back, this is one way to empower women in panjshir and to develop their economic dependency, the government is supporting their handicraft products and encouraging them to produce more, the ministry of women affairs have many activities that are helping women for their empowerment. The women in panjshir province are supported in agriculture production too, to enhance their agriculture production into their higher value and market based agricultural production. 
When Afghanistan was turned to the attention of international communities, the afghan economy growth have started very speedily, the private sector is supported by government and it is measured as an engine for the development of Afghanistan, the small enterprises are one part of the private sector in Afghanistan which makes job opportunity for people and is the way to support their daily life, panjshir province is one that places in the country that you can find many small enterprises in it, like fish farming, chicken husbandry or aviculture, clean drinking water factories and etc. this is what you can find now in the province, before 2000 there was no enterprises in panjshir province, the small enterprises in panjshir province of Afghanistan create many job opportunities for the residents of the province, the small enterprises are supporting by some international NGOs like USAID and others, people of panjshir province claimed that there is lack of markets for their products, they are asking the government to help them in finding good markets and places that they can sell their products, small enterprises can help the government economic growth if they are going to be support by government and other supporting agencies.

Construction of supporting walls beside the highway and rural roads are another achievement of rural development projects in panjshir province which is built it, these supporting walls in the roads are very important issue because panjshir province is one of the mountainous province of Afghanistan, and the highways are very dangerous due to the roads height because of the mountains and create a lot of challenges for drivers, these supporting walls are a kind of security for the drivers and people who are crossing the roads based on their daily business. There is thousand meters of supporting walls have built in panjshir province to secure the highways and the rural roads for residents of the province.

\section{Main changes of Rural Development in Panjshir}

The discussion below is stating the people's idea to compare their province rural development changes with other provinces of Afghanistan, as a resident of the province they are the only people who can share their experience 
regarding the rural development changes and be able to compare the province changes which is effected by the rural development projects in panjshir province, people have mentioned some changes and will be discussed below.

In comparison to other provinces panjshir province is developed well, than south and east provinces and the community has lots of facilities like panjshir now have a very high level of education centers, school and universities, health care centers, good public transport system, as mentioned in the analyzing of above questions asphalting of roads are the biggest achievement for panjshir province, kilometers of roads were constructed newly in panjshir province which in comparison to the past there was no asphalt road, now panjshir province is connected to the center of each individual districts of the province and big cities of Afghanistan.

Tele communication in Afghanistan was a big problem, during the Taliban regime in the country there was lack of communication system in Afghanistan which was a big challenge for the people, because there was no progress in tele communication system of the country, after the transition of the regime in 2001 the tele communication system was rapidly expanded to all over the country, the afghan government had begun the project of fiber cable in 2006 to connect the country, the mission of the fiber cable was to improve the telephone, internet, radio broadcast and television services all over the country, the communications system of Afghanistan is expanded and developed a lot especially in the last decade, many local and international investor have invested a lot in this sector to develop the country's communication system and help the people to connect with each other, panjshir province of Afghanistan is one of the those provinces that it is almost $100 \%$ covered by mobile tele communications company but still other provinces are not covered $100 \%$, this is what we are different from other provinces, as an example Badakhshan province is not completely covered by the tele communications services, where ever you go in panjshir, you are still connected and no worries to say that how can we contact others. 
More than thousands of families in some districts of Panjshir province, are facing a shortage of clean drinking water and it takes hours to get water from very long distances, people in panjshir province claimed that due to drought we have faced many problems to access for clean drinking water, but by the help of international NGOs we have solved this problem and now they have access to clean drinking water, digging wells for the people is an achievement in comparison to other provinces, because they wanted to access for clean drinking water in their province, people in panjshir province claimed that before digging wells in the province while we were using the water from the sea, our health was affected by different kind of sicknesses, now we are very lucky that we have access to clean drinking water by the help of international community and the government development projects, now we have good health and there is almost no problem in this regard because people have access to drinking water and many facilities for finding clean drinking water.

The implementation of rural development projects in panjshir province have affected on the people's daily life, as residents of the province mentioned in the questionnaire that poverty rate have been decreased due to construction of rural development projects, the literacy level of the residents have been improved because they can easily access to the schools and universities, in comparison to the past decade, panjshir province of Afghanistan is no more on that period since the number of education centers like schools, universities are increased that is why the literacy rate have increased.

People's unity is a very big achievement for the province development projects as the residents in the province said that many people in our province is working for some period of time free in their villages, they believe that if we do not built our village no body well help us, we are the only people for our village which we can help the rural development projects, this is also to be mentioned that lack of community participation is a reality in each province of Afghanistan and panjshir is not the exception. 


\section{Chapter V}

\section{Conclusions}

Due to security problems the investment of foreign aid in some part of the country is not properly organized but overall the effect of foreign aid is sensitive in the country's rehabilitation and reconstruction of new rural development projects, especially the panjshir province is one of the sample of rehabilitation in the infrastructure projects.

When Afghanistan was turned to the attention of international communities, the afghan economy growth have started very speedily and the rural development projects have been improved. The rural development projects have has improved and achieved many success, roads reconstruction in the country has started, many highways and rural roads were constructed and rehabilitated.

Roads are one of the country's biggest achievement in the past 15 years, building roads in the country is the priority for the Islamic Republic of Afghanistan, in past 10 years, government have built many kilometers of roads and bridges, the government aims to build roads in the country to make facilities and enable people to a transport system that can connect people inside and outside their communities, as well as enable people to access to the regions, people in panjshir province have said that before the year 2000 there was no asphalt roads in the province but now we have kilometers of asphalt roads.

People in Afghanistan are connected to the center of the provinces and other districts of the provinces and to the capital city Kabul, roads have brought many facilities like in the past people were unable to go from one province to another province and same in the provinces from one district to another district comfort and easy but now fortunately they can easily travel to other districts in the province and outside of the provinces to connect with the big cities like capital city Kabul. 
Because of good roads people are able to access the health and education centers very relaxed, people of Afghanistan and especially panjshir residents are very happy that the international community have helped the government of Afghanistan for building its infrastructure and still the people are looking forward to help them in advancing the life standards and development projects to improve more the rural areas. Rural areas of Afghanistan need a lot to be improved and the infrastructure should be the first priority.

Access to markets, education centers, healthcare centers and public services centers are the benefits that people are effected by foreign assistance, connection of villages to the center of districts and connection of districts to the province and also access of villagers to the markets, health care centers, schools are the effectiveness of foreign aid in panjshir province if you look back, 10 years ago there was lack of these services by the help of international communities now people are able to have these facilities in the province, now residents of panjshir province can easily carry out their products to the markets because of access to good asphalt roads, people in panjshir province have said that before the year 2000 there was no asphalt roads in the province but now we have kilometers of asphalt roads.

In comparison to other provinces panjshir have developed and improved, people's basic needs are available like they have, education centers, asphalt roads, good hospitals, clean drinking water and etc. but still need to work for the development of panjshir province.

The foreign aid has effected entirely the whole country's economic growth especially panjshir province is one of those provinces that is improved and enhanced in terms community economic development. The last 15 years for Afghanistan was a hope of better and modern life, in these recent years Afghanistan has past many political and social conflict and destruction, the country has started the process of reconstruction and rehabilitation and established a democratic government and was pursued to the urgent needs of the rehabilitation and development. The afghan government is committed for the 
sustainable and equal development in the country. All these commitment can bring prosperity and success to country's economic development and having better life for all residents of the country. By the help of questionnaire I found that many people in panjshir province thinks that without the help of international community we cannot achieve our economic growth that is help of them that we are now in this stage.

\section{Recommendations}

The billions of foreign aid to Afghanistan was aimed to make this country secure, independent and economically stable country, questions might be asked in terms of securing Afghanistan while the insurgent are still active in many areas of the country and are posing threats to the Afghan government in implementing the development projects which is the basic needs of the rural people. This is also notable that since the country was turned in to the attention of international community in 2001, I can surely say that Afghanistan has great achievements in implementing the infrastructure projects like education centers, making rural roads, health centers and so on, the foreign aid and contribution of international communities fairly useful, if not completely in making the country stable and establishing a democratic government in Afghanistan and helped the country stand side by side with its neighboring countries and globally.

I believe that billions of foreign aid could not be more effective unless we do not have good government, the afghan government and international community should take concrete steps in tackling widespread corruption and make the country peaceful, otherwise it is almost impossible to use the foreign aid transparently and successfully. Afghanistan will not have billions of foreign aid forever so that's why I recommend to the international communities and the Afghan government they have to focus on improvement of Afghan capacity building and making concrete steps for implementing the infrastructure projects. I tried in my thesis project to recommend the following points for both the 
Afghanistan government and the international community to organize the foreign aid for enhancing and strengthening communities in the country.

\section{To the Government of Afghanistan}

- I believes that development cannot occur if there is no secure places as first steps of the development, this is not only the problem of security which is effecting and stopping the developmental projects in the province but also can destroy the infrastructure and insecurity will cause development to go backward, the Afghan government should make a concrete steps to bring peace in the country for better implementation of foreign aid funded projects.

- Afghan government should make sure that there is no internal or external interference in the rural development projects which is funded by foreign aid. Government should eliminate the corruption in public and private sectors all over the country. They have to develop mechanisms for monitoring work in the Afghan government ministries and have to raise the public awareness also must punish the corrupt employees.

- Government should enhance the transparency of the external aid expenditure by making an effective aid spending procedure. They have to make honest and committed committee for allocation of foreign aid in the country. This committee must be responsible for both international community and the government of Afghanistan. The committee must share the data and information with public on frequent basis on the status of funding and programs implementation through Afghanistan's Ministry of Finance (MoF), Development Assistance Database, the Donor Financial Review and the annual Development Cooperation Report.

- Foreign aid must be spent on the Afghan capacity building to implement the commitment of the ANDS, government can improve the local government through the provincial government in the country, they have to focus on the capacity building of the local authorities, and the 
government should delegate the sufficient authority to the local governments. Government must ensure that provincial governments, provincial directorates and other relevant local authorities including the Provincial Development Councils (PDCs) and Community Development Councils (CDC) have sufficient resources in hand to execute, monitor and evaluate the development programs in all provinces.

- A commission of aid spending should be created by both Afghan government and the international community to identify the basic needs of the people and urgent projects in rural areas of Afghanistan specifically in panjshir province of Afghanistan. They have to monitor the development projects which is going to be funded by foreign aid in the country, this is one way that they can spend foreign aid transparently and effectively and aid must be used properly to eradicate the poverty in the country also International community should take care of their aid to the government of Afghanistan that is not misused. They should not give the lead to the corrupt officials.

- To increase the efficiency of the development projects, the government must decrease the level of contracting with private sectors instead they should increase the role of Afghan organizations and Non-Government Organizations (NGOs) to get better result in the implementation of rural projects.

- Assist the Afghan government in strengthening and implementing the rule of law to counter insurgency in Afghanistan by building capacity of the Afghan National Security Forces (ANSF) and improving the quality, quantity, competence and expertise of the Afghan forces to fight insurgency and pave way for implementing development programs throughout the country.

- Based on my findings the panjshir people wanted to use the foreign aid on the infrastructure projects, also the data analysis shows that many people thinks that foreign aid is used properly in the rural development projects of their province and there are other people whom they are thinking that 
foreign aid is not used properly based on their need and rural development projects of their province. Government should pay attention to the needs of the people in the provinces.

\section{To the international Community}

- The donor countries should provide sufficient and timely aid for the country's development process and avoid rapid and major cuts in Aid which this makes the country's development process slow. The international colleagues have to increase and extend their contribution with the Afghanistan government outside the capital city Kabul and the ministries they have to include the provincial governments, provincial development councils, community development councils to identify the needs in the rural area of Afghanistan, they can easily find the needs of rural areas through the CDCs and local governments for better implementation of the development projects.

- The international community should increase their network with the local authorities in the community level to achieve the sustainable development goals and to demonstrate the needs of people in the local communities. In making the network with local authorities, donors could prioritize the funds for essential rural services, especially they have to focus on rural roads, education centers and health care centers.

- The donors must ensure that aid is spending on public areas and for better lives of Afghan People, the international community must also make sure that every single development project is sustainable and for a long time and should respond the basic needs of the rural people.

- Donors should increase the predictability of aid by more determined efforts to fulfill their aid promises and providing more multi-year aid commitments. Donors should provide greater support to the civil reconstruction and development process. 
- For the use of aid in a proper way in the rural development of the country we need strong leadership and project management that we can use aid based on peoples need, the government should take care of its developmental projects and must look back to the maintenance of rural development projects and all developmental projects, if the projects will not maintenance I can surly say that, life of the projects will decrease to its lowest rate and finally we might not have development in the country.

- The international community should know that aid is using based on the people's need, the aid to recipient countries must help poor people and reduce the rate of poverty, and aid should come with the price of its own to the developing countries and must respond the need of people otherwise if the aid from donor to recipient nations does not respond their need, surly that is priceless and I cannot call it aid and helping people, in this regard I will say that aid from donor to the developmental nations must target the peoples need, targeting the peoples need itself is fight against poverty.

- Foreign aid must help the process of development projects in a country or a community which must help the poorer people of that area. If the foreign aid will not help the process of development projects, that is misused and the donors must find the problem for the project implementation also they can crosscut the aid to the projects. 


\section{References}

Adina, M. S. (2013). Adina, Sabir. Mohammad (2013), "Wardak seeks \$3b in aid for school buildings". Retrieved on Oct 13, 2013 from http://www.pajhwok.com/en/2013/05/18/wardak-seeks3b-aid-schoolbuildings.

AfghanistanCompact. (2006). Building on Success The London Conference on Afghanistan .

Akbari, M. R. (2016). Role of Government in Rural Development of: Comparison between Afghanistan National Solidarity Program and South Korea Saemaul Undong.

ANDS, G. o. (2008-2013). Afghanistan National Development Strategy 2008 2013. A Strategy for Security, Governance, Economic Growth \& Poverty Reduction. Kabul.

ANDS, I. R. (2008/09). FIRST ANNUAL REPORT 1387 (2008/09) MAKING A DIFFERENCE: TRANSITION FROM PLANNING TO PRACTICE. THE GOVERNMENT COORDINATION COMMITTEE (GCC).

ANDS, S. (2007). The provincial development plan and regional consultation. Kabul: Government.

ArabNews. (2013). Arab News (2013), "Emirates to commence daily service to Kabul". Retrieved on Oct 17, 2013 from http://www.arabnews.com/news/464866.

BankWorld. (2012). World Bank report (2012) International Development Association and International Finance Corporation Interim Strategy Note for Islamic Republic of Afghanistan. Retrieved September 14,2012.

BBC, N. (2008). BBC (2008), "Karzai opens Kabul air terminal". Retrieved on Oct 23, 2013 from http://news.bbc.co.uk/2/hi/south_asia/7713796.stm. BBC.

CIA. (2015). The World Factbook. CIA. Retrieved 5 September 2015. 
Eric Davin , G. (2008). AID EFFECTIVENESS IN AFGHANISTAN

PAPER PREPARED FOR THE PARIS CONFERENCE -

JUNE 2008 Commissioned by the French Government . Kabul:

Altai Consulting .

Hamayoon, K. (2015). The Effectiveness of Foreign Aid on Afghanistan

Development: Is there Any lesson Kabul Can learn from the Korean

Experience.

Malcolm, M. (2003). Rural development principles and practice. London: ISBN 07619-4766-3.

Ministry of Finance, I. R. (2012). Aid Statistics Report. Kabul: Ministry of Finance.

Ministry of Public Health, M. (2013). Ministry of Public Health (2013), "MoPH Holds Health Retreat Conference in Kabul". Retrieved on Sep 29, 2013 from http://moph.gov.af/en/news/19187. Kabul.

MoPH. (2009-2013). Afghanistan Comprehensive Health Information System Strategic Plan. Ministry of Public Health .

MRRD, M. o. (2016). http://mrrd.gov.af/en/page/40 MRRD introduction 2016,11. Kabul: MRRD web page.

National Rural Access Programme, N. (2016). Introduction of NRAP Retrieved from: http://www.nrap.gov.af/?page_id=414. Kabul: NRAP/MRRD.

NationalAcademyPress. (1987). Infrastructure for the 21st Century. Washington, D.C.: National Academy Press,.

NRAP, A. R. (2014). National Rural Access Programm (NRAP) Annual Report. Kabul: NRAP.

NSP, N. S. (2015). http://www.nspafghanistan.org/index.aspx. Kabul, Afghanistan: NSP Web site.

RailwayGazette. (2011). Railway, Gazette (2011), "First major Afghan railway completed". Retrieved on Oct 18, 2013 from http://www.railwaygazette.com/news/single-view/view/first-majorafghanrailway-opens.html. 
Raqeebi, M. M. (2013). External Aid And Its Effectiveness In The Reconstruction And Development Of Afghanistan - An Analysis Of The Years 2002-2014.

Shah, A. P. (2009). POLICY PROCESS STUDIES Policymaking in Agriculture and Rural Development in Afghanistan. Kabul: Afghanistan Research and Evaluation Unit Case Study Series.

Totakhail, M. L. (2011). Foreign Aid and Economic Development in Afghanistan .

UnitedNationsDevelopmentProgram. (2013). United Nations Development Program (2013), "International Human Development Indicators". Retrieved on Sep 30, 2013 from http://hdrstats.undp.org/en/countries/profiles/AFG.html.

Waldman, M. (2008). FALLING SHORT, Aid Effectiveness in Afghanistan . ACBAR ADVOCACY SERIES.

Williams, M. J. (2011). NATO, the Comprehensive Approach and State-building in Afghanistan. Online.

WorldBank. (2013). The World Bank (2013), "Mobile cellular subscriptions (per 100 people)". Retrieved on Sep 23, 2013 from http://data.worldbank.org/indicator/IT.CEL.SETS.P2 . 


\section{Appendixes}
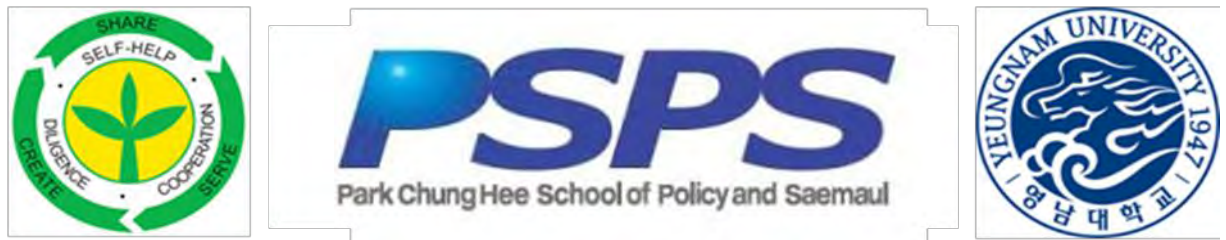

Yeungnam University

\section{Park Chung Hee School of policy and Saemaul}

\section{Thesis Questionnaire}

You are invited to participate in a thesis writing survey. This questionnaire is to gather the primary information for a thesis project titled "The Effectiveness of Foreign Aid in Rural Development of Afghanistan (A Case study in Panjshir Province of Afghanistan)". For this survey, you don't need to write your name and personal information, completion of this survey will take approximately 1015 minutes; your honest replies are highly appreciated. You are kindly requested to select only one appropriate answer to each of the questions based on the instruction given above each section. The information provided will be used only for the preparation of a thesis project report; we promise to not disclose the given information for any other purpose.

Your responses are valuable to us, thank you in advance for the cooperation.

Interview date: 2016 / / Questionnaire\#: (00) Place of Research: Panjshir 
Specification of the respondents for research demographics please select only on applicable:

1- Sex: Male $\square$ Female

2- Age: 18 to $30 \square 31$ to $40 \square 41$ to $50 \square 51$ or above

3- Marital Status: Married $\square$ Single

4- Job Status: government employee $\square$ Business Man $\square$ student Jobless

5- Education Status: Illiterate $\square$ School graduate $\square$ Bachelor $\square$ Master PHD

\section{Questions:}

Q 01: Does Afghanistan need more Foreign Aid for its Rural Development?

1- Yes $\square \quad 2$ - No

Please rate how much you personally agree or disagree to the statements bellow:

Q 02: Infrastructure is the priority for sustainable rural development in Panjshir province.

1-Strongly Agree $\square$ 2- Agree $\square$ 3- Uncertain $\square$ 4- Disagree $\square$ 5Strongly Disagree

Q 03: Foreign aid has been used properly in rural development of Afghanistan so far.

1-Strongly Agree $\square$ 2- Agree $\square$ 3- Uncertain $\square$ 4- Disagree $\square$ 5Strongly Disagree 
Q 04: Foreign aid has been used in Panjshir province based on understanding of people's need.

1-Strongly Agree $\square \quad$ 2- Agree $\square \quad$ 3- Uncertain $\square \quad$ 4- Disagree $\square \quad$ 5Strongly Disagree

Q 05: Foreign Aid helped the process of rural development in Panjshir province.

1-Strongly Agree $\square \quad$ 2- Agree $\square$ 3- Uncertain $\square \quad$ 4- Disagree $\square \quad$ 5Strongly Disagree

Q 06: Rural development should be the first priority of government for utilizing Foreign Aid.

1-Strongly Agree $\square$ 2- Agree $\square$ 3- Uncertain $\square$ 4- Disagree $\square \quad$ 5Strongly Disagree

Q 07: Aid is required to address the short-term challenges and sustainable poverty reduction in the Panjshir province.

1-Strongly Agree $\square$ 2- Agree $\square$ 3- Uncertain $\square \quad$ 4- Disagree $\square \quad$ 5Strongly Disagree

Q 08: Aid is centralized and top-heavily focusing on Kabul and other urban cities.

1-Strongly Agree $\square$ 2- Agree $\square$ 3- Uncertain $\square \quad$ 4- Disagree $\square \quad$ 5Strongly Disagree 


\section{To the questions bellow please provide your point of view in brief}

Q 09: what is the main problem of rural development in your province, please briefly explain?

Q 10: What is the effect of foreign aid in rural development of your province?

Q11: As a resident of the province could you please explain what kind of changes do you see in your province, which have been effected by rural development projects?

Q 12: In comparison to other provinces what is the main changes of rural development in Panjshir province, please briefly explain?

Q 13: Do you believe that foreign aid is helpful for the developmental projects in the country?
1- Yes
2- No
3- Maybe

Source: the questionnaire above is designed based on researcher's understanding from the literature review and the Afghan society. 


\section{Korean Abstract}

아프가니스탄 농촌개발에 대한 해외원조의 효과성 아프가니스탄 판즈시

$$
\text { 르주의 사례 }
$$

\section{아막일 사다왈리}

\section{영남대학교 박정희새마을대학원}

새마을국제개발학과 새마을운동및실천전공

\section{지도교수 박승우}

요약

본 연구의 목적은 아프가니스탄 농촌 개발에서의 대외 원조 효과 성을 검토하고자 함이다 (아프가니스탄 판지시르 주의 사례 연구). 국제 사회와 원조 공여국들이 15 년 이상 아프가니스탄 이슬람 공화국 정부에 안보 및 개발, 인도주의적 원조를 제공해오면서 아프가니스탄은 2002년 이후로 계속해서 발전해왔고 여러 농촌 지역에서 중요한 성과를 거두어왔 다.

본 연구의 정보는 1 차 및 2 차 정보 자료에서 발췌한 것이다. 2차 정보 수집을 위해 책, 학술지, 연구 논문을 참고하였으며 1차 정보는 주로 설문지 활용 및 아프가니스탄 판지시르 주 거주자 직접 방문을 통해 수집 하였다. 
대외 원조의 기여 덕분에 아프가니스탄 내 농촌 지역이 발전하였 으며, 특히 판지시르 주는 농촌진흥 및 경제적 측면에서 좋은 성과를 보여 주었다. 아프가니스탄의 농촌 개발 프로젝트는 뛰어난 성과를 거두었고 농촌 지역의 상당한 발전을 이루어냈다. 아프가니스탄 농촌 개발 기구는 농촌 지역의 확장과 농촌 지역 거주민들의 발전을 위해 많은 노력을 기울 였으며 이를 통해 다수의 교량, 도로, 교육 기관, 의료 기관들이 새로 건설 되거나 복구되었다. 2014 년 기준으로 총 $1,400 \mathrm{~km}$ 의 도로 및 1,600 개의 교 량이 새롭게 건설되었으며 NRAP 농촌 기구를 통해 수백만 시간에 달하는 노동이 창출되었다. 